Report of Investigations 2014-4

\title{
GEOLOGIC MAP OF THE SOUTH-CENTRAL SAGAVANIRKTOK QUADRANGLE, NORTH SLOPE, ALASKA
}

by

R.J. Gillis, P.L. Decker, M.A. Wartes, A.M. Loveland, and T.D. Hubbard

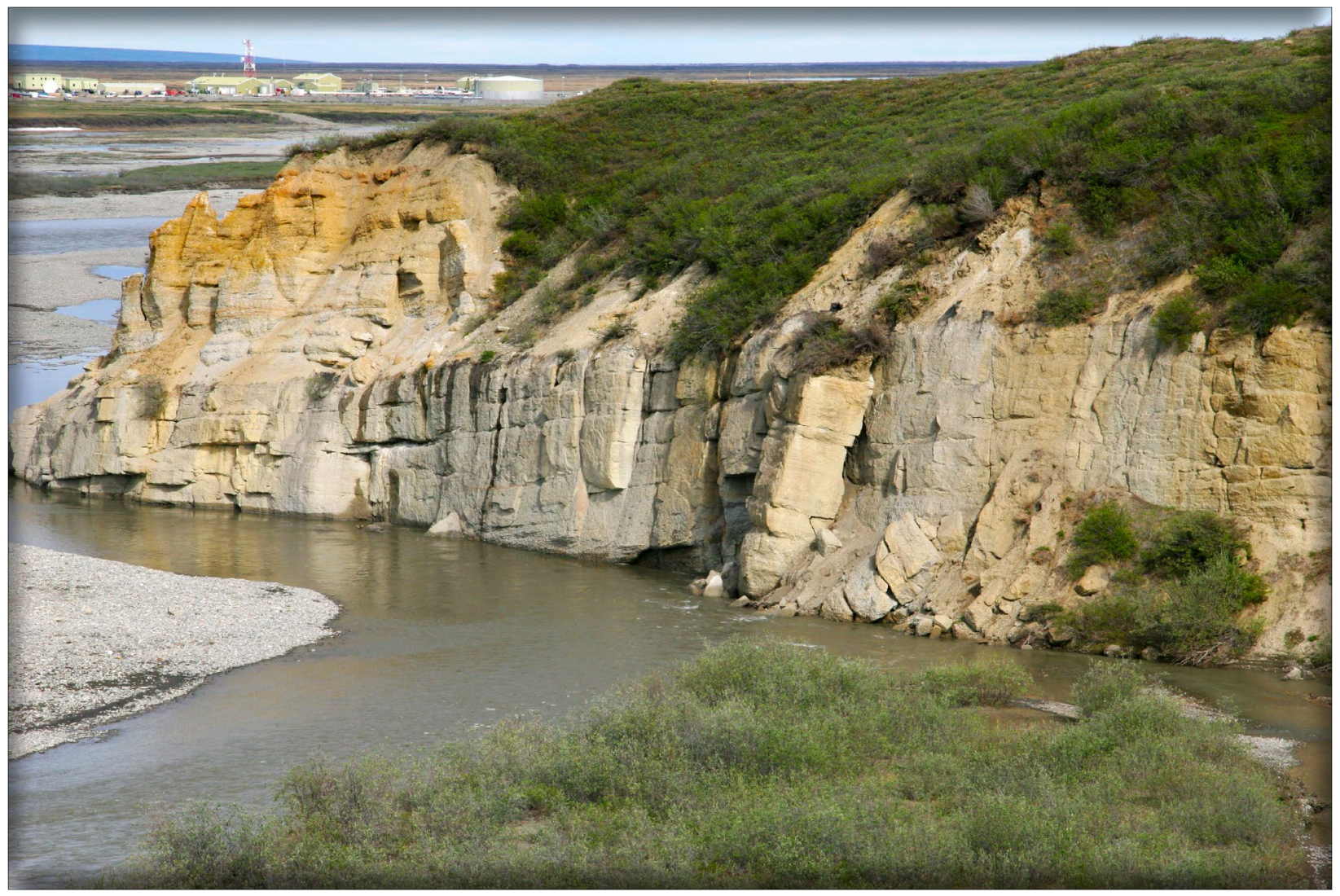

Sagwon Member of the Sagavanirktok Formation forms the east bank of the Sagavanirktok River; the formation is tilted gently toward the northwest. Trans-Alaska Pipeline System Pump Station \#2 in background.

\section{Published by}

STATE OF ALASKA

DEPARTMENT OF NATURAL RESOURCES

DIVISION OF GEOLOGICAL \& GEOPHYSICAL SURVEYS 


\title{
Report of Investigations 2014-4
}

\section{GEOLOGIC MAP OF THE SOUTH-CENTRAL SAGAVANIRKTOK QUADRANGLE, NORTH SLOPE, ALASKA}

\author{
by \\ R.J. Gillis, P.L. Decker, M.A. Wartes, A.M. Loveland, and T.D. Hubbard
}

2014

This DGGS Report of Investigations is a final report of scientific research.

It has received technical review and may be cited as an agency publication. 



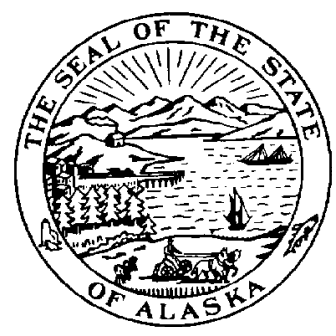

STATE OF ALASKA

Sean Parnell, Governor

DEPARTMENT OF NATURAL RESOURCES

Joe Balash, Commissioner

DIVISION OF GEOLOGICAL \& GEOPHYSICAL SURVEYS

Steven Masterman, State Geologist and Director

Publications produced by the Division of Geological \& Geophysical Surveys (DGGS) are available for free download from the DGGS website (www.dggs.alaska.gov). Publications on hard-copy or digital media can be examined or purchased in the Fairbanks office:

\section{Alaska Division of Geological \& Geophysical Surveys 3354 College Rd., Fairbanks, Alaska 99709-3707 \\ Phone: (907) 451-5020 Fax (907) 451-5050 \\ dggspubs@alaska.gov \\ www.dggs.alaska.gov}

\begin{abstract}
Alaska State Library
State Office Building, 8th Floor 333 Willoughby Avenue

Juneau, Alaska 99811-0571

Elmer E. Rasmuson Library

University of Alaska Fairbanks

Fairbanks, Alaska 99775-1005
\end{abstract}

\author{
Alaska Resource Library \& Information \\ Services (ARLIS) \\ 3150 C Street, Suite 100 \\ Anchorage, Alaska 99503-3982 \\ University of Alaska Anchorage Library \\ 3211 Providence Drive \\ Anchorage, Alaska 99508-4614
}

This publication released by the Division of Geological \& Geophysical Surveys was produced and printed in Fairbanks, Alaska, at a cost of $\$ 28.00$ per copy. Publication is authorized by Alaska Statute 41, which charges the division "to determine the potential of Alaskan land for production of metals, minerals, fuels, and geothermal resources; the location and supplies of groundwater and construction materials; the potential geologic hazards to buildings, roads, bridges, and other installations and structures; and shall conduct such other surveys and investigations as will advance knowledge of the geology of Alaska." 


\section{CONTENTS}

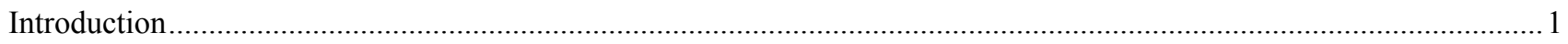

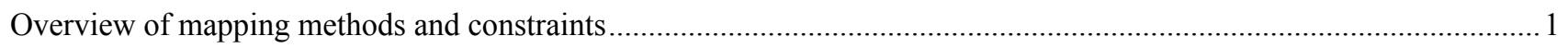

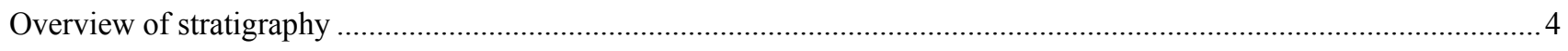

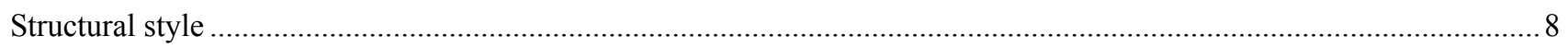

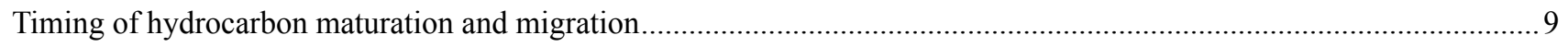

Discussion of the timing of deformation and exhumation, and their implications ........................................................

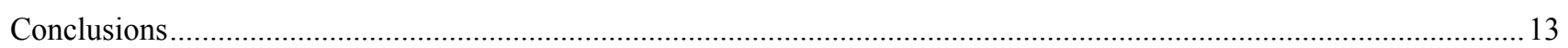

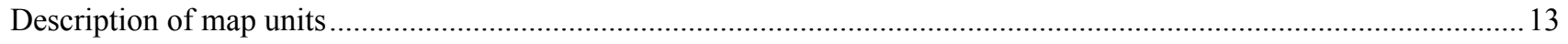

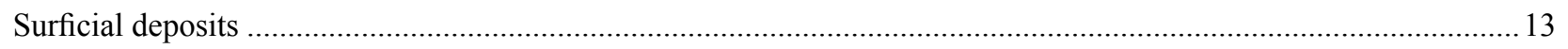

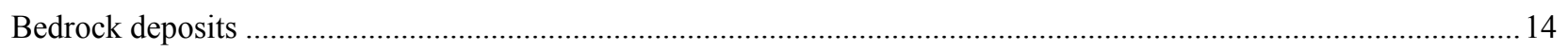

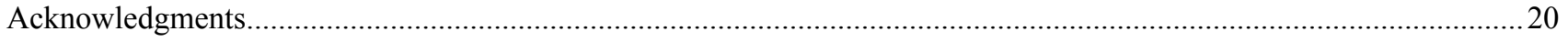

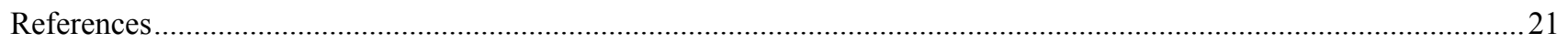

\section{FIGURES}

Figure 1. Station location map showing the distribution of $\sim 800$ bedrock stations visited during the 2008 field

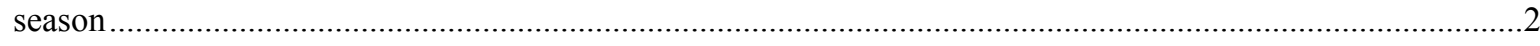

2. Shaded-relief map of the study area and locations of wells and major physiographic features ..........................

3. Stratigraphic cross section constrained by four wells in or near the map area ..................................................5

4. Chronostratigraphic column for the Colville basin, Alaska............................................................................

5. View to the north along the Sagavanirktok River at Sagwon Bluffs .............................................................

6. Tight, small-scale folding of Canning Formation strata exposed in the core of the Kuparuk anticline on

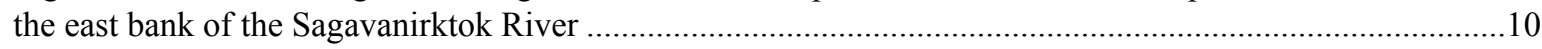

7. Age vs. measured-depth plots of previously published apatite fission-track data for the Susie Unit 1, Aufeis Unit 1, and Lupine Unit 1 wells

\section{SHEETS}

Sheet 1. 1:63,360-scale geologic map of the south-central Sagavanirktok Quadrangle, North Slope, Alaska

2. Diagrammatic cross section oriented approximately perpendicular to the main structural trend through the Lupine Unit 1 and Susie Unit 1 wells. 



\title{
GEOLOGIC MAP OF THE SOUTH-CENTRAL SAGAVANIRKTOK QUADRANGLE, NORTH SLOPE, ALASKA
}

\author{
by \\ R.J. Gillis ${ }^{1}$, P.L. Decker ${ }^{2}$, M.A. Wartes ${ }^{1}$, A.M. Loveland ${ }^{1}$, and T.D. Hubbard ${ }^{1}$
}

\section{INTRODUCTION}

Despite proximity to the Dalton Highway and the TransAlaska Pipeline corridor, the east-central foothills of the North Slope remain only lightly explored by drilling, and have not been mapped in detail. Previous bedrock investigations in the Sagavanirktok River area are limited to reconnaissance-level 1:1,000,000-scale maps by Lathram (1965) and Grybeck and others (1977), road log figures by Mull and Harris (1989), and unpublished inch-to-mile mapping by Gil Mull. This new geologic mapping of the southwest and south-central Sagavanirktok Quadrangle at 1:63,360 scale was completed through the combination of field mapping and stratigraphic studies by the Alaska Division of Geological \& Geophysical Surveys (DGGS) and the Alaska Division of Oil and Gas (DOG) in the summers of 2007 and 2008. The map area is bisected by the Dalton Highway, the Sagavanirktok River, and the Trans-Alaska Pipeline System Pump Station 2 (near the north edge of the map), and encompasses approximately $3,100 \mathrm{~km}^{2}\left(1,200 \mathrm{mi}^{2}\right)$ of the Sagavanirktok A-3, A-4, B-3, B-4, and parts of A-2, A-5, B-2, and B-5 1:63,360-scale quadrangles. The mapping builds on existing published and unpublished mapping by DGGS and others (Mull and Harris, 1989). Stratigraphic units identified on the map are based on the revised nomenclature of Mull and others (2003) with further refinement from recent and concurrent stratigraphic studies (Decker, 2007; Decker and others, 2008; LePain and others, 2008; Wartes and Decker, 2008).

This mapping effort differed from previous DGGS foothills projects by substantially incorporating subsurface interpretations of well $\log$ and seismic data with traditional field mapping, aerial photograph interpretation, and analytical results from samples collected in the field. The integration of surface and subsurface data facilitated working farther into the basin where sparsely distributed bedrock exposures have hindered accurate regional-scale bedrock mapping in the past. This strategy allowed for mapping of a region encompassing most of the Brookian sequence and has provided valuable insight into how mechanical stratigraphy influenced structural style and location of deformation as well as the time-transgressive northeastward progradation of genetically related shelf, slope, and basin facies and associated lower- and higher-order sequence boundaries. More detailed discussion of the map area structures, stratigraphy, and their regional implications can be found in the following sections and unit descriptions accompanying this report.

\section{OVERVIEW OF MAPPING METHODS AND CONSTRAINTS}

Rock unit identification, bedding attitudes, structural observations, hydrocarbon indications, and analytical data from samples collected at field stations (fig. 1) were used to ground-truth and refine preliminary geologic interpretations based in part on subsurface data. Approximately 420 line $\mathrm{km}$ (260 line $\mathrm{mi}$ ) of proprietary two-dimensional (2-D) seismic reflection data through the map area (seven dip lines and three strike lines) were interpreted by P.L. Decker prior to 2008 field activities, integrating available surface information and subsurface correlations in the Lupine Unit 1, Aufeis Unit 1, Ivishak Unit 1, and Echooka Unit 1 wells in the map area and the Susie Unit 1, Nora Federal 1, and Bush Federal 1 wells nearby to the north (figs. 2 and 3). The seismic data were useful in constraining the continuity and plunge of major structures and in projecting lithologic and structural contacts into areas of significant Quaternary cover where surface constraints were limited or lacking. Map unit and fault contacts and fold axial traces are shown as black lines where field evidence constrains their position. Red lines represent contacts and axial traces that are constrained entirely by subsurface information. Rubble traces and traceable beds evident from aerial photography and topography helped define folds and other structures, contributing to the map interpretation in areas of little or no intact bedrock outcrop. In most cases, rubble traces were visited to confirm formation assignments and all interpretations were reconciled with available subsurface information. Generalized Quaternary units were mapped only in larger river drainages and areas of thick Quaternary cover where the subcropping units could not be confidently identified. Therefore, the distribution of bedrock as mapped intentionally overrepresents the amount of bedrock encountered in the field to more clearly represent regional-scale stratigraphic and structural relationships. A Quaternary geologic map of the same area will shortly follow publication of this bedrock geologic map (Hubbard and others, in preparation).

The structural cross-section (sheet 2) is somewhat diagrammatic, as no attempts were made to balance unit lengths or magnitude of shortening. However, surface and well constraints were honored for defining structural geometries and stratigraphic thicknesses, and 2-D seismic sections (scaled in two-way travel time) subparallel to the line of structural section helped inform geologic interpretations at

\footnotetext{
${ }^{1}$ Alaska Division of Geological \& Geophysical Surveys, 3354 College Rd., Fairbanks, Alaska 99709-3707; robert.gillis@alaska.gov; marwan.wartes@alaska.gov; trent.hubbard@alaska.gov

${ }^{2}$ Alaska Division of Oil \& Gas, 550 W 7th Ave., Suite 1100, Anchorage, Alaska 99501-3560; paul.decker@alaska.gov
} 


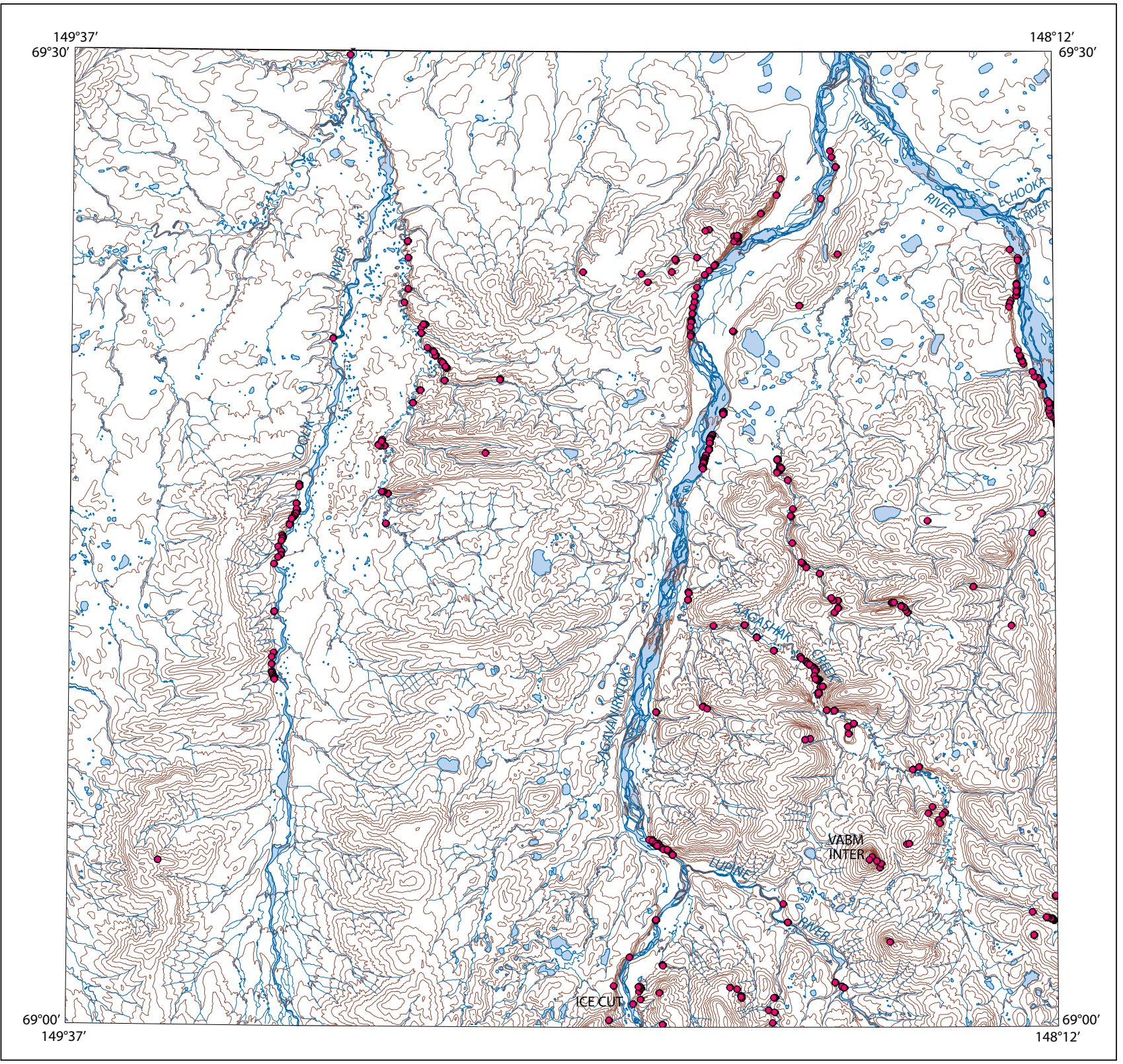

Figure 1. Station location map showing the distribution of 800 bedrock stations (marked by fuchsia dots) visited during the 2008 field season. Because of widespread Quaternary cover, most surface bedrock exposures were found along river cuts. A combination of surface mapping, air photo interpretation, and subsurface interpretations from well and seismic data provided more complete representation of the map area.

depth. The quality of the seismic expression broadly varies with latitude, time (depth), and structural position for most lines. The quality of the time sections tends to improve northward (basinward), and stratigraphic reflections are generally well expressed down to the top of the Kingak Shale as constrained by horizon picks in the Lupine Unit 1 and Susie Unit 1 wells (fig. 3). Ellesmerian and older rocks beneath the Kingak Shale are less clearly resolved in the seismic data, particularly to the south where folds and thrusts are more prevalent. A significant acoustic impedance contrast generates a relatively recognizable reflection at the approximate stratigraphic position of the Lower Cretaceous unconformity ( $\mathrm{LCu}$ ) or its correlative conformity, at or near the top of the Kingak Shale. This reflectivity likely represents the acoustic contrast between the pebble shale unit and/or Kemik Sandstone relative to the overlying gamma ray zone (GRZ) of the lower Hue Shale and the underlying Kingak Shale. Common thrust imbrication of this prominent reflection is consistent with high-frequency, small-displacement imbrication of the Kemik Sandstone and pebble shale unit observed in outcrop to the northeast along the Canning River (Wartes and others, 2011b). The vertical position of the reflection also helps to 


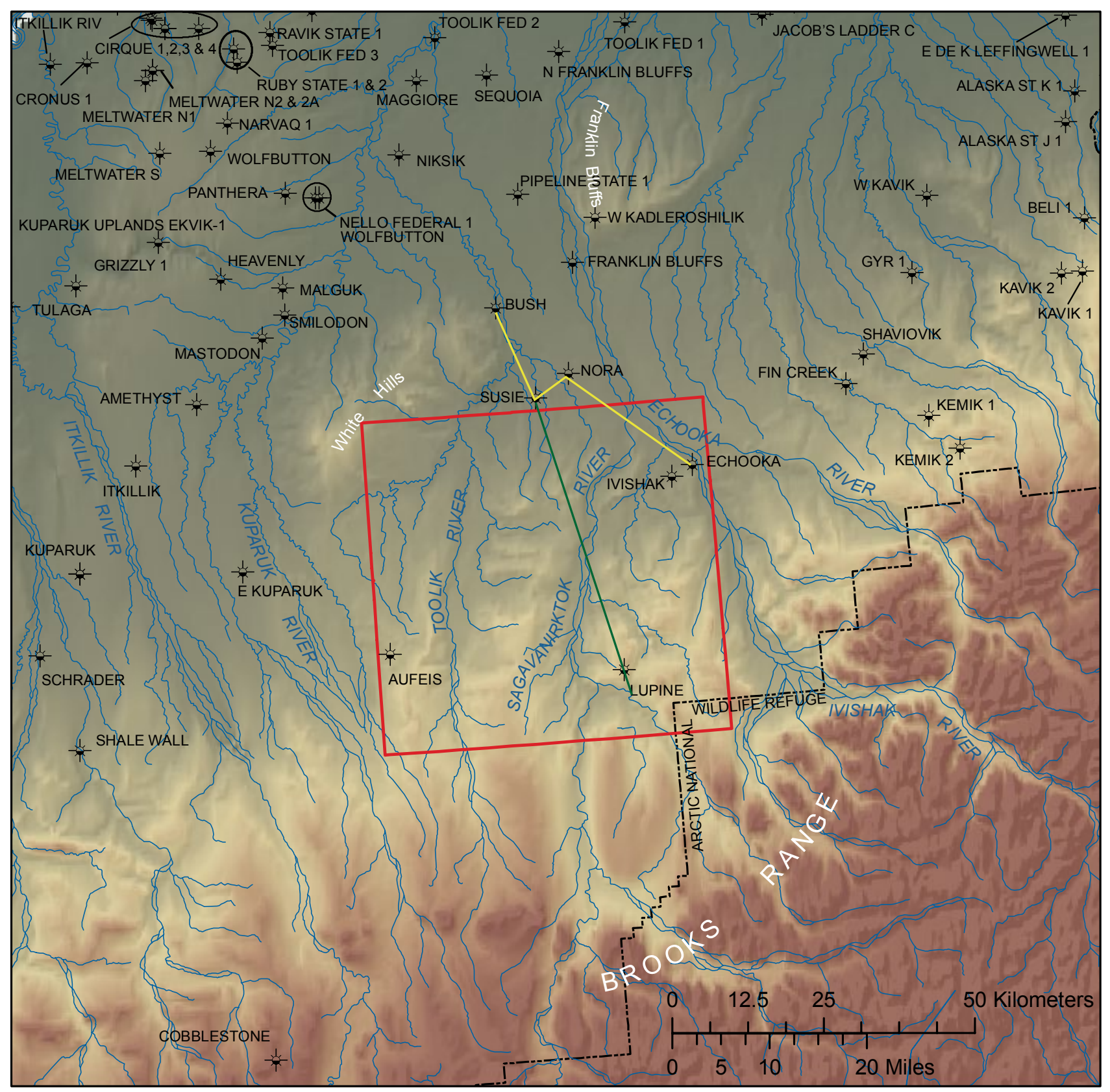

Figure 2. Shaded-relief map of the study area (outlined in red) and locations of wells and major physiographic features. Well correlation line (fig. 3 ) is shown in yellow. Line of structural section (sheet 2 ) is shown in green.

constrain distributed structural thickening in the Kingak Shale interval and the amount of offset across southward-dipping, low-angle discontinuities observed in the seismic profiles and interpreted as thrust faults.

The location and geometry of faults depicted in the subsurface was influenced greatly by seismic observations, specifically the interpretation of displaced, truncated, and folded reflections tied to the well control in the area. Little attempt was made to create arbitrary structures to fill space in the cross section in order to balance the interpretation, or to make it conform to a particular structural style. Faults in the cross section are dashed where they deviate significantly from the seismic interpretation, typically in an effort to reconcile the location of folds with respect to fault cut-offs and to minimize gross discrepancies in the distribution of shortening throughout the section.

Synclinal geometries are particularly well expressed in seismic sections beneath the mapped traces of the Sagashak and Toolik synclines and unnamed synclines north of the Kuparuk anticline. The cores of tightly folded anticlines are less well resolved due to steepening of fold limbs toward the axial plane and internal deformation concentrated at fold 
hinges, both of which tend to attenuate the acoustic signal. Such internal deformation is visible in outcrop near the hinge of the Kuparuk anticline along the east bank of the Sagavanirktok River, where tight parasitic folding and faulting of relatively incompetent Canning Formation strata occurs at multiple scales. Near the northern edge of the map area, the Sagwon and Susie anticlines are well imaged seismically, owing to their open fold geometries, coherent stratigraphy, and apparently limited internal thrusting.

\section{OVERVIEW OF STRATIGRAPHY}

The map area includes a significant portion of the Brookian sequence, with surface exposures generally younging northward and ranging from Albian to Paleocene in age (fig. 4). These rocks include the Torok through Sagavanirktok Formations that are derived from the Brooks Range orogen and reflect progressive filling of the Colville foreland basin via both transverse and axial sediment dispersal systems (Bird and Molenaar, 1992). Northeastward progradation of genetically related nonmarine, shelf, slope, and basin floor depositional systems has resulted in the time-transgressive association of formations across the basin (fig. 4). In the map area, unit designations build from the regional nomenclature revised by Mull and others (2003). A key component of this stratigraphic subdivision is the application of unit names based in part on their interpreted position in the depositional profile (topset, foreset, or bottomset). This is facilitated by the recognition of sedimentary facies indicative of specific depositional settings, including features such as trace fossil assemblages or style of cross stratification. See unit descriptions for further discussion of map unit criteria and interpreted environments.

The new mapping and associated stratigraphic studies resulted in improved criteria for subdividing the stratigraphy into depositional cycles (Decker, 2007). In particular, we find that the record of major rises in relative sea level, often represented by condensed sections, can be readily recognized. As depicted in figure 4, these flooding surfaces and episodes of sediment starvation are associated with significant landward shifts in the paleoshoreline in the Cenomanian-Turonian (between Torok and Seabee Formations), Santonian (between Seabee and Canning Formations), and middle Campanian (between middle and upper Schrader Bluff formation). In the map area, these transgressive events give rise to abrupt decreases in grain size and often produced comparatively recessive, subdued topography.

The integration of regional subsurface data also informed the interpretation of depositional setting and correlation of units, resulting in an improved understanding of regional stratigraphic relations and, in places, significant changes in formation assignment in the map area. The following list summarizes the notable new or revised stratigraphic interpretations in the map area and nearby regions:

Torok Formation-A number of prior mapping and stratigraphic studies in the Sagavanirktok and Ivishak rivers region assigned Albian strata to the Nanushuk Formation (Keller and others, 1961; Huffman and others, 1985; Mull and Harris, 1989). The Nanushuk is widely regarded as a topset unit, dominated by fluvial, shoreface, and shelfal facies (Mull and others, 2003; LePain and others, 2009). However, Albian rocks in the region exhibit features consistent with sediment gravity flow deposition, most likely in a deep-water setting (Molenaar and others, 1984; Schenk and Bird, 1993; LePain and others, 2002; Decker and others, 2008). Based on these facies and correlations with regional seismic data, we deem it more appropriate to label these rocks as Torok Formation, which is elsewhere ascribed to slope and basin floor facies that are downdip equivalents to the Nanushuk Formation (fig. 4). In addition, interpretation of seismic data indicates that the Torok Formation thins markedly from south to north across the map area (sheet 2), a characteristic that is consistent with regional observations (Detterman and others, 1975; Molenaar and others, 1983; Decker and others, 2008).

Seabee Formation - We assign the name Seabee Formation to a mappable succession of Turonian-Coniacian(?) rocks that represent deep-water equivalents of the Tuluvak Formation (LePain and others, 2008; fig. 4). Most prior descriptions of this unit have focused on strata much farther west (Houseknecht and Schenk, 2005), although seismic data demonstrate that it thickens markedly to the east (Mull and others, 2003; Decker, 2007).

Unnamed Tongue of Hue Shale - In the map area, the Seabee Formation is overlain by a thin succession of organic-rich shale and bentonite of probable Santonian age (LePain and others, 2008). Although too thin to map at 1:63,360 scale, we infer the interval represents a tongue of the condensed Hue Shale (fig. 4), reflecting a significant transgressive episode. This interval is also recognized in nearby wells (fig. 3).

Lower Schrader Bluff and Canning Formations-Based on regional subsurface data, Decker (2007) suggested a regional subdivision of the shallow marine to shelfal Schrader Bluff Formation into lower, middle, and upper parts. The type section for the formation lies well west of the map area and appears to only represent the lower part of the formation as now understood. Furthermore, we interpret the lower Schrader Bluff to be absent in the map area, having been either truncated by a major middle Campanian unconformity (Decker, 2007), or transitioned basinward into slope facies of the Canning Formation (LePain and others, 2008). The recognition of Canning Formation strata in the map area is new, extending the known outcrop of the unit more than $40 \mathrm{~km}(25 \mathrm{mi})$ farther west (prior western mapped limit in Reifenstuhl and others, 2000). Nevertheless, use of the term Canning Formation for deeper-water equivalents to the Schrader Bluff Formation comports with subsurface cross sections and nomenclature suggestions in Molenaar and others (1986).

Middle and upper Schrader Bluff Formation-Regional well log, seismic, and outcrop studies suggest the map area includes both the middle and upper parts of the Schrader 


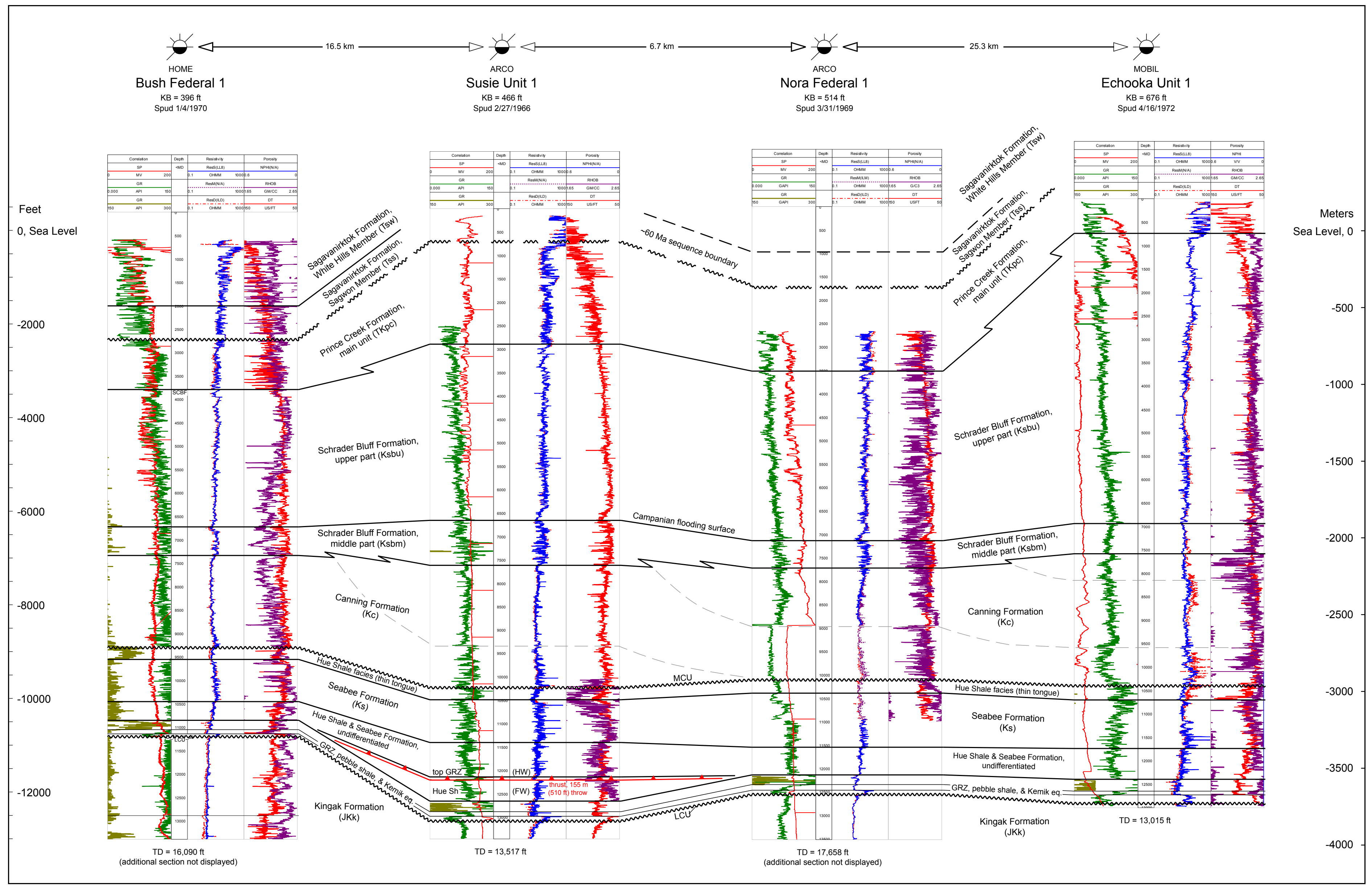

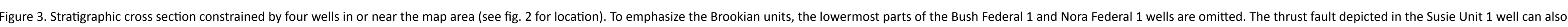
be seen in cross section (sheet 2); HW = hanging wall, FW = footwall. Stratigraphic picks and correlations by P.L. Decker. 


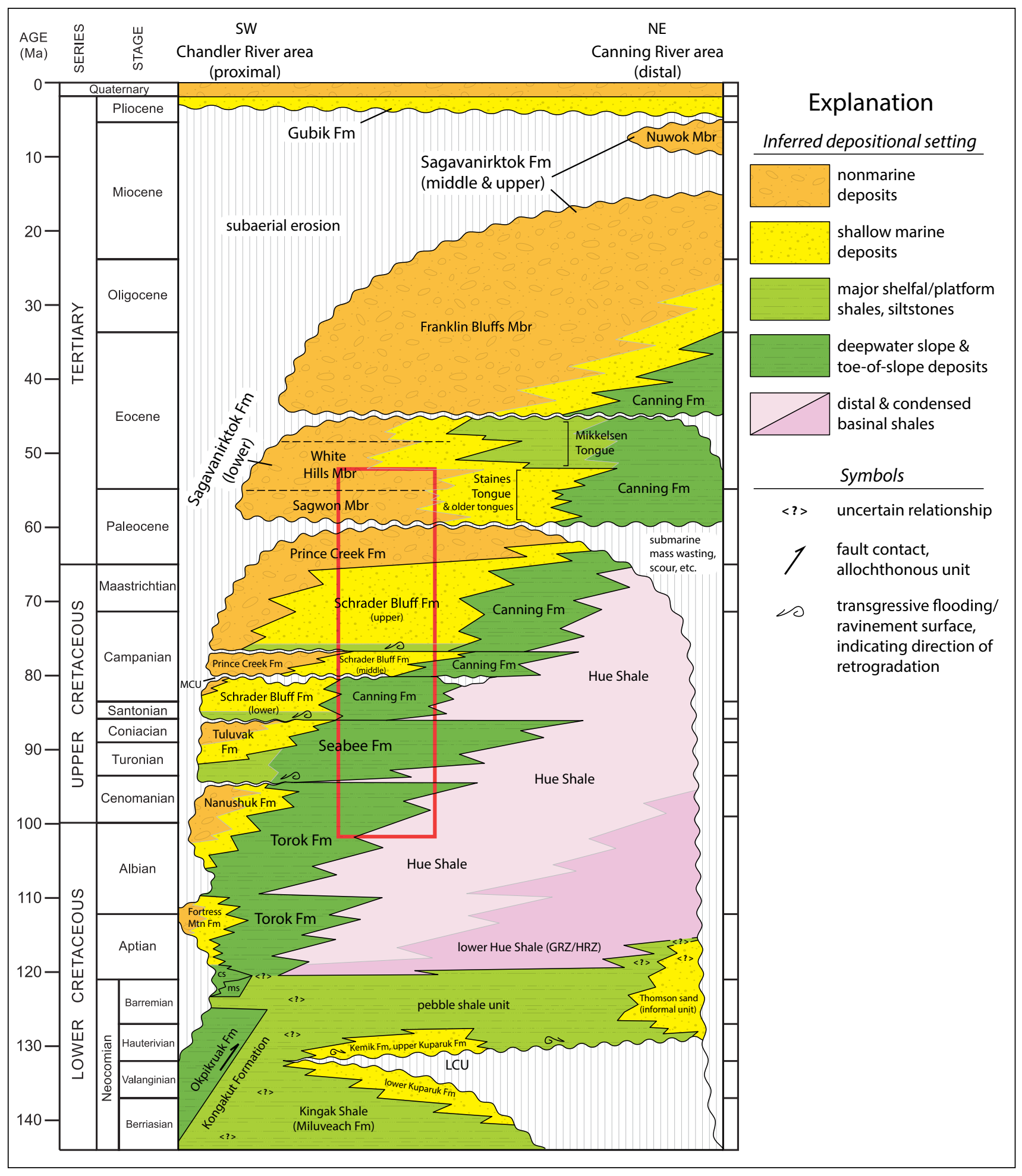

Figure 4. Chronostratigraphic column for the Colville basin, Alaska, revised from Mull and others (2003) and Garrity and others (2005). Abbreviations as follows: Fm = Formation; Mbr = Member; Mtn = Mountain; LCU = Lower Cretaceous unconformity; $\mathrm{MCU}=$ mid-Campanian unconformity; $\mathrm{cs}=$ Cobblestone sandstone of Fortress Mountain Formation (informal); $\mathrm{ms}=$ manganiferous shale unit (informal). The red box approximates stratigraphy exposed in map area. 
Bluff Formation, as subdivided by Decker (2007). The middle Schrader Bluff overlies the Canning Formation and is interpreted to reflect a major episode of basinward progradation (fig. 4). The middle and upper Schrader Bluff are separated by a regionally significant flooding surface that is readily correlated in well logs (fig. 3 ) and reflected in outcrop as a major recessive interval (LePain and others, 2008).

Lower Tongue of the Prince Creek Formation-The nonmarine Prince Creek Formation typically overlies the marine Schrader Bluff Formation (Mull and others, 2003). However, the two formations are regionally understood to be timetransgressive, with the Prince Creek grading basinward into Schrader Bluff (fig. 4). In the western part of the map area, we recognized a mappable tongue of nonmarine facies between the marine middle and upper Schrader Bluff formations. This lower tongue of the Prince Creek does not extend eastward to the Sagavanirktok River, suggesting that the nonmarine facies mark the eastern limit of the paleoshoreline associated with the middle Schrader progradation. Similar intertonguing of Prince Creek and Schrader Bluff facies has been noted in the Colville River area (Flores and others, 2007a).

Paleocene unconformity at base of Sagavanirktok Formation - Mull and others (2003) revised the lower boundary of the Sagavanirktok Formation, placing the contact at a conspicuous white-weathering conglomerate exposed along Sagwon Bluffs (fig. 5). Based on our mapping, we concur that this is a more readily mappable surface than that proposed by Detterman and others (1975). Further, we agree with recent studies that consider the contact to be a major Paleocene sequence boundary (Mull and others, 2003; Daly and others, 2011). Abrupt changes across the unconformity include an increase in grain size, notable differences in sandstone and clast composition, and an interpreted reduction in the sinuosity of the fluvial system. These observations are interpreted to record an increase in gradient and sediment supply associated with renewed uplift in the Brooks Range and partial exhumation of the Cretaceous foreland basin (Wartes and others, 2011a). This suggested link is consistent with regional structural and thermochronologic data indicating major uplift in northern Alaska occurred in the Paleogene (O'Sullivan and others, 1997; Moore and others, 2004).

\section{STRUCTURAL STYLE}

Deformation in the Sagavanirktok map area is characterized by thin-skinned contractional structures in a mainly hindward-dipping fold-thrust system. Shortening was accommodated by east-northeast- and northeast-trending, mostly north-verging thrust faults and associated fault-propagation and fault-bend folds. Strata truncated by the modern-day surface decrease in age northward, reflecting a southwardthickening structural wedge. The style and location of deformation in the map area was greatly influenced by the relative strength of the prograding sedimentary packages. Deformation in the map area is entirely thin-skinned, with the Kingak Shale at about 3,660-4,880 m ( 12,000-16,000 $\mathrm{ft})$ below the surface serving as the principal structural detachment and a major interval of structural thickening.

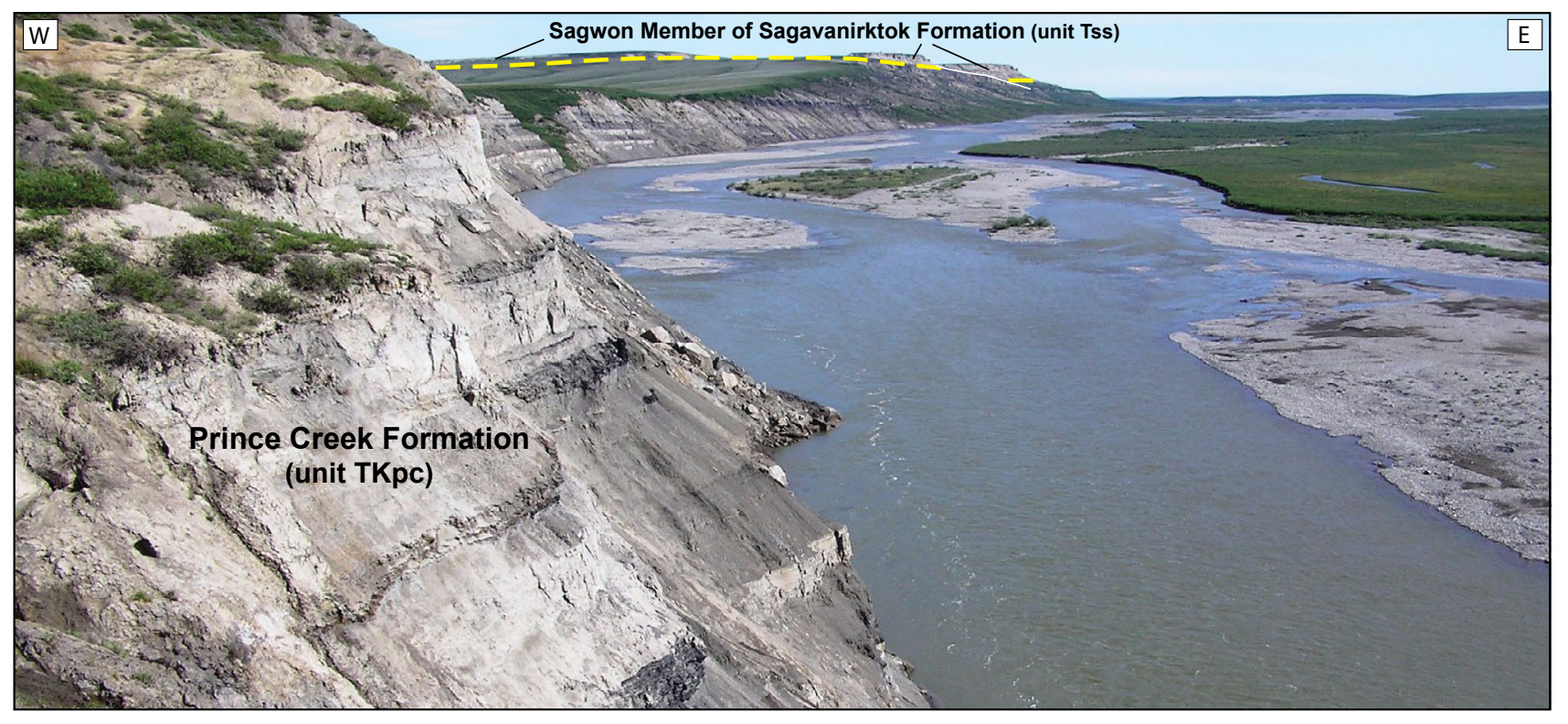

Figure 5. View to the north along the Sagavanirktok River at Sagwon Bluffs. The Maastrichtian(?) to Paleocene Prince Creek Formation in the foreground and middle distance is dominated by interbedded meandering fluvial sandstone, floodplain siltstone, and mire facies coal and carbonaceous mudstone. These strata are disconformably overlain by lithologically distinct fluvial conglomerate and sandstone of the Paleocene Sagwon Member of the Sagavanirktok Formation, shown on the skyline near VABM Gard. These exposures are accessible by hiking 0.8-2.4 km (0.5 to $1.5 \mathrm{mi}$ ) east from the Dalton Highway (northern half of Township 1 South, Range 14 East and the southern half of Township 1 North, Range 14 East, Umiat Meridian). See map sheet for location. 
Thickening of up to $\sim 1,800-2,100 \mathrm{~m}(\sim 6,000-7,000 \mathrm{ft})$ in the Kingak Shale is interpreted to occur from distributed folding and faulting within weak shales across a continuum of scales. Thrust flats in this interval transfer slip to higher levels via thrust ramps inferred from seismic sections that cut across mechanically more competent lithologies. Deformation in the hindward region of the structural wedge is controlled by mechanically strong sand-prone strata that often form large fault ramps, which promote substantial structural thickening. These sandier strata thin basinward, giving way to finergrained, mechanically weaker facies. The most mechanically competent strata in the map area occurs in the Torok Formation, which becomes thicker and more sand-prone toward the south and east (for example, Gilead Sandstone exposed approximately $20 \mathrm{~km}$ [12 mi] due east of the map area [Decker and others, 2008]), but wedges out altogether in the subsurface to the north. The Icecut and Lupine thrusts, which breach the surface in the southeastern region of the map area, expose the deepest structural levels represented by Albian-Coniacian Torok and Seabee Formation sandstone and lesser siltstone and shale, and produce $\sim 1,500-2,000$ $\mathrm{m}(\sim 4,900-6,500 \mathrm{ft})$ or more of stratigraphic separation, respectively. To the north of the Lupine thrust, most discrete faulting is restricted to a relatively stronger interval of Torok and Seabee strata confined between the mechanically weak Kingak Shale regional detachment and thin turbidites of the stratigraphically higher Canning Formation, although both weak units can be substantially deformed internally as well. An excellent example of distributed shortening in Canning Formation rocks can be observed directly east of the map area, where the strata are complexly folded and faulted for nearly a kilometer normal to strike in bluffs along the west bank of the Ivishak River.

The magnitude of shortening along most major faults varies along trend over distances of tens of kilometers, resulting in gentle fold plunges that yield numerous three-way, and some apparent four-way fold closures at the surface. The Aufeis and Kuparuk anticlines are narrower, symmetric to slightly asymmetric, and each has at least two four-way closures separated by saddles near the west side of the Sagavanirktok River valley. The largest synclines (Toolik and Sagashak) are open, broad, symmetrical, and doubly plunging. The low density of exploration drilling, common oil and gas shows in the subsurface, and hydrocarbon indications in outcrop, together with a structural style characterized by four-way fold closures and relatively few surface-breaching thrust faults, all suggest the area may host untested structural traps. Small-scale faulting and tight parasitic folding occur near cores of larger folds at several locations, such as the east bank of the Sagavanirktok River in the hinge zone of the Kuparuk anticline in relatively incompetent Canning Formation strata (fig. 6).

\section{TIMING OF HYDROCARBON MATURATION AND MIGRATION}

Oil staining in Maastrichtian(?)-Paleocene (Prince Creek Formation) and older strata at several locations in the map area support the occurrence of hydrocarbon migration in the region since early Cenozoic time. Moreover, occurrences of hydrocarbon-saturated sandstone concentrated at or near most anticlinal crests in the map area (see sheet 1 for oil-stained localities) suggests that potential trapping geometries had formed prior to, or concurrently with, thermal maturation and migration of liquid hydrocarbons.

\section{DISCUSSION OF THE TIMING OF DEFORMATION AND EXHUMATION, AND THEIR IMPLICATIONS}

Contraction must have initiated after early(?) Campanian time (approximately $83 \mathrm{Ma}$ ) in the map area to the south and continued until at least late Paleocene time (approximately $60 \mathrm{Ma}$ ) to the north based on deformation of the youngest exposed strata in those areas ( $\mathrm{Kc}$ and Tss, respectively). The stratigraphic constraints are consistent with other regional data indicating an important phase of latest Cretaceous to Paleocene (at about $60 \mathrm{Ma}$ ) deformation across the western and central Brooks Range foothills (O'Sullivan and others, 1997; Moore and others, 2004).

New analysis of previously published but uninterpreted apatite fission-track (AFT) data from three map area wells (Lupine Unit 1, Aufeis Unit 1, and Susie Unit 1) further constrain the timing and sequence of local deformation. These data vary in quality and completeness, but indicate that cooling, presumably in part by exhumation from contractional faulting at depth and fold growth (for example, O'Sullivan and others, 1993; O'Sullivan, 1996), occurred during Paleocene to Eocene time from about 60 to $34 \mathrm{Ma}$ (fig. 7). Only sample ages that pass a chi-squared statistical test for single grain-age populations (chi-squared probability $>5 \%$ ) (Galbraith, 1981) and with negligible grain age dispersion $(<10 \%)$ (Galbraith and Laslett, 1993) were considered in the following interpretations. All filtered ages are younger than the strata from which they were sampled (fig. 7) and suggest complete, or nearly complete annealing of apatite grains from burial heating. The ages are youngest in the southernmost Lupine Unit $1(43.7 \pm 4.7$ to $33.9 \pm 4.4 \mathrm{Ma})$ and northernmost Susie Unit $1(44.4 \pm 5.5$ to $44.4 \pm 4.9 \mathrm{Ma})$ wells (fig. 7). Filtered ages from the Aufeis Unit 1 well are older $(60.2 \pm 6.2$ to $50.3 \pm 6.0 \mathrm{Ma}$ [fig. 7]) and may record an earlier period of cooling, or have not experienced additional reheating after resetting. Thus, peak burial occurred prior to $60 \mathrm{Ma}$ at the Aufeis Unit 1 well location, and before about $44 \mathrm{Ma}$ at the Lupine Unit 1 and Susie Unit 1 wells locations. 


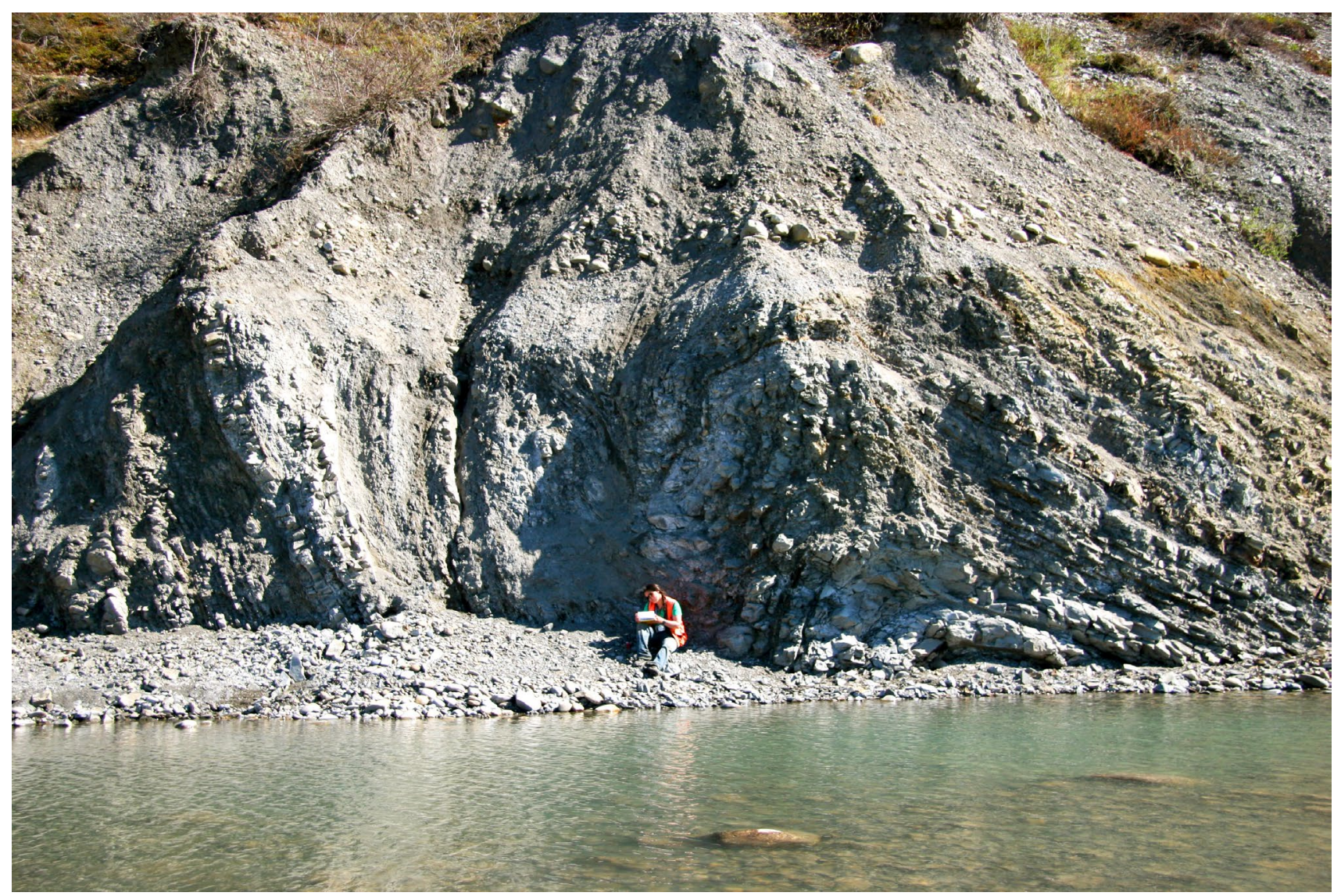

Figure 6. Tight, small-scale folding of Canning Formation strata exposed in the core of the Kuparuk anticline on the east bank of the Sagavanirktok River. Thinly-bedded, fine-grained and mechanically weak Canning Formation sediment gravity flow deposits serve as an intermediate level detachment interval in the map area, and are commonly complexly deformed in outcrop, especially near anticlinal hinges. Geologist for scale. View to east.

The filtered AFT ages from map area wells can be grouped into two, and possibly three, cooling domains beginning at $\sim 60,44$, and $34 \mathrm{Ma}$ whose timing are in good agreement with major episodes of deformation and cooling at 60, 46, and $35 \mathrm{Ma}$ inferred from AFT results along the northern inner foothills of the Philip Smith Mountains directly to the southeast (O'Sullivan and others, 1998). Sixty-million-yearold cooling ages occur throughout much of the Brooks Range and exhumed foreland basin, and have been interpreted to represent widespread, probably thin-skinned shortening and exhumation in the northern foothills at that time; generally associated with east-striking structures (Blythe and others, 1996; O'Sullivan and others, 1997, 1998; Moore and others, 2004). By contrast, 45 and 35 Ma cooling is more commonly recognized in the northeastern salient and often associated with northeast- and east-striking structures that sometimes involve basement shortening, such as in the Sadlerochit and Shublik mountains (O'Sullivan and others, 1998; O'Sullivan and Wallace, 2002). The 45 and 35 Ma deformation fronts defined by the surface distribution of AFT ages episodically young toward the southeast and are interpreted to represent exhumation cooling driven by hindward-migrating deformation in a foreland-directed fold-thrust system (O'Sullivan and
Figure 7 (right). Age vs. measured-depth plots of previously published apatite fission-track (AFT) data for the Susie Unit 1 and Aufeis Unit 1 wells (Mooney, 2006), and Lupine Unit 1 well (Geologic Materials Center, 1990). Symbols plotted at midpoint of sampled intervals. Ages in bold type and cyan-colored circles are pooled ages that pass the chi-squared statistical evaluation for a single grain-age population $(>5$ percent) and possess low ( $<10$ percent) grain-age dispersion; italicized values and yellow circles represent central ages that fail the chi-squared test and represent mixed age populations. Error bars are 1 sigma. Colored lines represent stratigraphic age intervals of formations penetrated by the wells (truncated at $100 \mathrm{Ma})$. Tss = Sagwon Member of the Sagavanirktok Formation, TKpcu = upper Prince Creek Formation, $\mathrm{Ksb}=$ Schrader Bluff Formation (undivided), $\mathrm{Kc}=\mathrm{Can}-$ ning Formation, $\mathrm{Ks}=$ Seabee Formation, $\mathrm{Kt}=$ Torok Formation, LTF = Lupine thrust fault. Red histograms represent the track-length distribution of measured, confined fission-tracks for each sample. MTL = mean track length, Std Dev. = standard deviation of track lengths, $\mathrm{n}=$ number of measured, confined track lengths. 


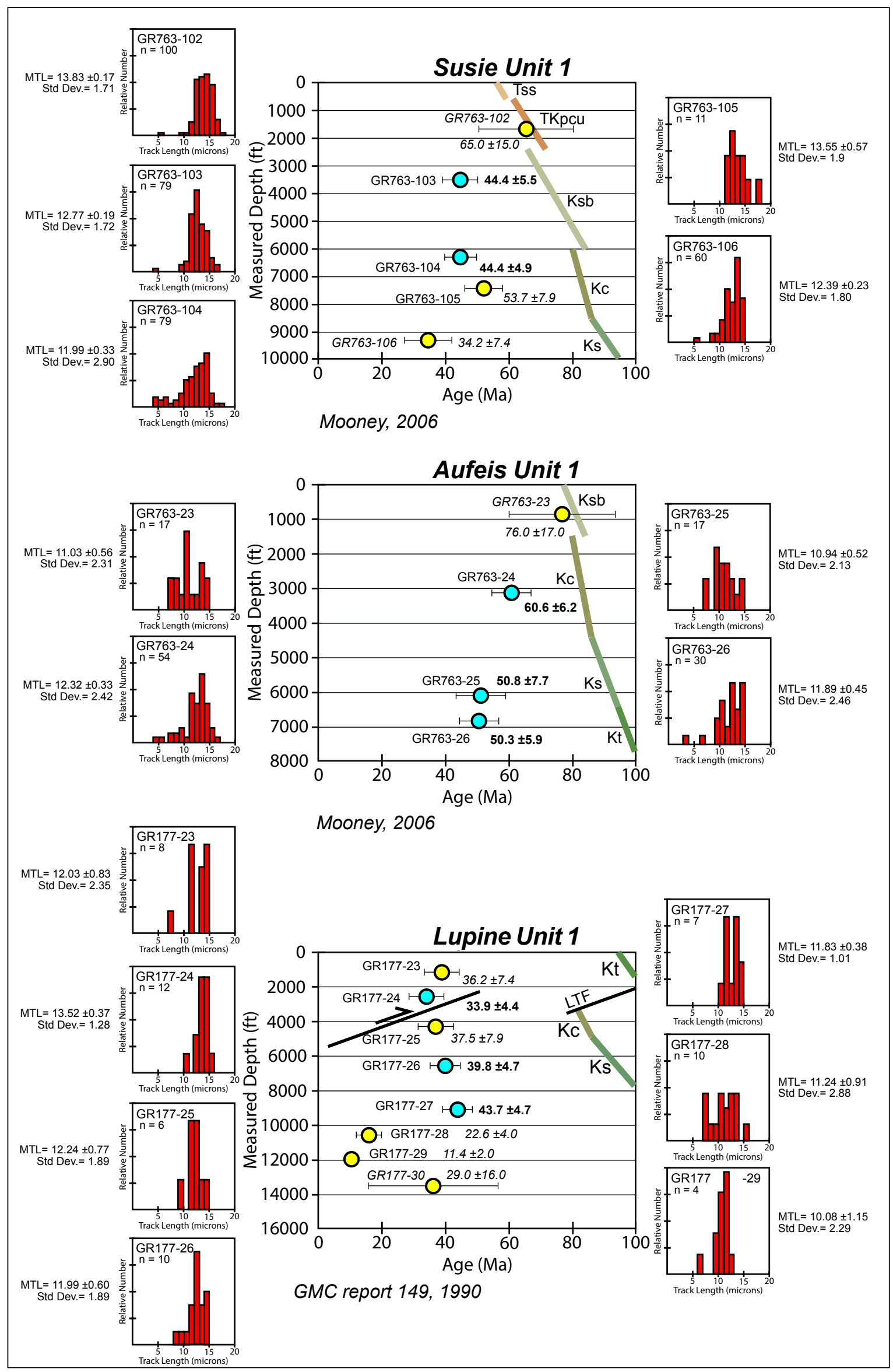


others, 1998). A general southeastward-younging of AFT cooling ages from the map area wells is in broad agreement with the deformation fronts as defined by O'Sullivan and others (1998), which trend northeastward across the southeast corner of the Sagavanirktok map area, subparallel to some mapped structures. However, when comparing the amount of structural thickening estimated from the cross section to the vertical distribution of cooling ages from the wells, it is clear that tectonic exhumation associated with mapped structures may not be the principal driver of the observed cooling (see below).

AFT sample ages plotted against measured depth for the Lupine Unit 1, Aufeis Unit 1, and Susie Unit 1 wells (fig. 7) reveal that significantly thick intervals $(\sim 1-3 \mathrm{~km}[0.6-1.9$ mi]) of Albian- to Paleocene-age strata cooled during relatively narrow windows of time during late Paleocene to early Eocene and middle to late Eocene. However, there is poor agreement between the magnitude of structural thickening estimated from the cross section and degree of cooling in some cases, and it is apparent that not all of the cooling can be explained by structural exhumation above the Kingak detachment. A generally positive correlation between age and measured depth (increasing age with decreasing depth) suggests limited structural thickening of the drilled intervals occurred along discrete faults during or after samples cooled below the nominal AFT annealing temperature of $\sim 110^{\circ} \mathrm{C}$. An exception may be the Lupine thrust, for which late Eocene cooling of its hanging-wall strata may postdate middle Eocene cooling of its footwall (fig. 7c). Although better data from the Lupine structure is needed to substantiate this inference, if correct, then $\sim 34 \mathrm{Ma}$ hanging-wall cooling that postdates $\sim 44 \mathrm{Ma}$ footwall cooling appears to be consistent with out-of-sequence shortening proposed for the Philip Smith Mountains foothills at 45 and $35 \mathrm{Ma}$ (O'Sullivan and others, 1998).

Below, we estimate the magnitude of removed section above each well location using the shallowest filtered (completely reset) AFT pooled ages and an assumption of a Paleogene geothermal gradient of $29^{\circ} \mathrm{C} / \mathrm{km}$ from O'Sullivan (1999). The reset ages reflect the time at which the samples began cooling below $\sim 110^{\circ} \mathrm{C}$, therefore, an estimation can be made about the shallowest depth at which the samples began cooling based on the paleogeothermal gradient value. The difference between the estimated depth of cooling and their current depth reflects the amount of stratigaphic section removed by erosion. The paleogeothermal gradient estimate of O'Sullivan (1999) is based on the integration of AFT and vitrinite reflectance results from eight North Slope wells. Estimates of denudation above the Lupine Unit 1, Aufeis Unit 1, and Susie Unit 1 well locations using AFT results presented here agree with denudation magnitudes independently estimated from compaction curves for each of the map area wells from Burns and others (2007), which are insensitive to heat flow. Therefore, $29^{\circ} \mathrm{C} / \mathrm{km}$ appears to be a reasonable approximation of the Paleogene geothermal gradient in the map area.
Depths to the shallowest filtered (completely reset) ages range from about $1,980-945 \mathrm{~m}(6,500$ to $3,100 \mathrm{ft})$ (fig. 7) and suggest a minimum of $1,420-2,450 \mathrm{~m}$ (4,650 to $8,050 \mathrm{ft}$ ) of exhumation since late Paleocene to middle Eocene time, assuming a paleogeothermal gradient of $29^{\circ} \mathrm{C} / \mathrm{km}$ and after subtracting approximately $400 \mathrm{~m}(1,300 \mathrm{ft})$ of "apparent" exhumation from late Oligocene-Miocene climate cooling (O'Sullivan, 1999). However, when compared to estimates of structural thickening above the basal décollement (as constrained by well logs and vertical position of the wellresolved $\mathrm{Khs} / \mathrm{Kps} / \mathrm{Kk} / \mathrm{LCU}$ interval from seismic profiles; sheet 1), only cooling ages from the southernmost Lupine Unit 1 well can be explained by thin-skinned deformation alone and only if a minimum estimate for exhumation is assumed. By contrast, the Aufeis Unit 1 well interval located downplunge of the line of section on the western margin of the map area has been structurally exhumed by an estimated $1,700 \mathrm{~m}(\sim 5,600 \mathrm{ft})$, yet cooling ages suggest a minimum of $2,855 \mathrm{~m}(\sim 9,360 \mathrm{ft})$ of denudation has occurred above the structure, resulting in $\sim 1,145 \mathrm{~m}(\sim 3,760 \mathrm{ft})$ or more of exhumation that cannot be accounted for by thickening in or above the basal detachment.

Constraints on the amount of contractional thickening for the Susie anticline derived from well logs, cuttings, and wellresolved seismic sections are more robust, and indicate only about $150 \mathrm{~m}$ ( $\sim 500 \mathrm{ft}$; sheet 2$)$ of structural relief has been created above a relatively thin Kingak décollement. However, the AFT data suggests more than $2,740 \mathrm{~m}(>\sim 8,990 \mathrm{ft})$ of denudation from above the detachment. AFT results from the northernmost Susie Unit 1 well are compatible with the $\sim 2,135 \mathrm{~m}(\sim 7,000 \mathrm{ft})$ magnitude of unroofing independently estimated from sonic-porosity logs from the same well (Burns and others, 2007), and thermal modeling of a partially-reset AFT surface sample $(\sim 2,400 \mathrm{~m}$, or 7,870 ft) collected from the Sagavanirktok Formation at nearby Sagwon Bluffs (O'Sullivan, 1996). This indicates that a mechanism other than thin-skinned deformation above a relatively shallow structural detachment is required to properly interpret cooling ages from the east-central foothills. A similar mismatch in the magnitude of exhumation inferred from AFT data and the amount of relief generated by thin-skinned deformation has also been recognized in the northeastern salient of the Brooks Range by O'Sullivan and Wallace (2002). They concluded that shortening along basement fault ramps that sole into a deeper structural detachment was also required to generate the relief necessary to honor the cooling data. However, unlike with basement-cored uplifts exposed at the surface in the northeastern Brooks Range, there is no evidence for sufficiently large discontinuities between inferred Brookian and older strata from map area seismic profiles to suggest significant basement structure at depth, nor is there evidence for a down-to-the-north step in regional basement elevation from well penetrations that argue for major basement ramp basinward of the map area. Thus, care should be taken in ascribing erosion above growing structures as the principal driver of cooling in this region of the foreland basin unless 
the magnitude and distribution of structural thickening is well understood.

The apparent northward transition from largely shortening-driven exhumation to exhumation in the absence of substantial shortening documented in the map area is significant, because it may help explain an enigmatic pattern of contemporaneous Cenozoic cooling and exhumation that occurs from the deformed frontal wedge of the Brooks Range to the undeformed distal foreland basin. Several different datasets including AFT thermochronology (Murphy and others, 1994; Blythe and others, 1996; O'Sullivan, 1996; Cole and others, 1997; O'Sullivan and others, 1997; Chmielowski and others, 2000; O'Sullivan and Wallace 2002; Moore and others, 2004; Mull and others, 2009; and Houseknecht and others, 2011), thermal maturity-depth trends (Howell and others, 1992; O'Sullivan, 1999; Burns and others, 2007), and compaction-depth trends (Nelson and Bird, 2005; Burns and others, 2007) indicate contemporaneous $60 \mathrm{Ma}$ and younger Brooks Range contraction and widespread denudation of the Colville foreland basin extending well beyond the deformation front. The mechanism(s) driving uplift and denudation of the basin is poorly understood, but published models range from post-orogenic isostatic rebound of the thrust wedge and foredeep over a thermally-equilibrating crustal root (Howell and others, 1992), flexural response to active thrust loading in the orogenic wedge (McMillan and O'Sullivan, 1992), or elements of both (Hubbard and others, 1987). Recent studies favor episodic Brooks Range deformation during Cenozoic time (for example O'Sullivan and others, 1997; O'Sullivan and Wallace 2002; Moore and others, 2004). However, simultaneous thickening of the orogenic wedge and exhumation of the foredeep region of the Colville foreland basin is difficult to reconcile with flexural models predicting foredeep subsidence in response to tectonic loading of an elastic or visco-elastic lithosphere (for example Beaumont, 1981; Jordan, 1981; Watts and others, 1982). Structural constraints and cooling data from the map area suggest a transition from principally upper crustal deformation-driven denudation toward the hinterland to the south to lower or subcrustal controls of uplift and denudation of the gently-deformed foreland basin near the toe of the thrust wedge. Although these new insights alone do not identify the driving mechanism for regional Cenozoic exhumation of the foreland basin, they may help constrain future attempts at basin modeling.

\section{CONCLUSIONS}

The integration of surface observations and subsurface data in the Sagavanirktok area yield valuable new stratigraphic and structural insight into an area that until recently has been poorly understood. The strategy helped to document time-transgressive, northeastward-prograding Albian-Paleocene foreland basin strata deformed in a northward-propagating Campanian or younger thin-skinned fold-thrust system at a level of detail significantly greater than would have been possible by field mapping alone.

An improved understanding of regional stratigraphic correlations and depositional environments resulted in a geologic map that explicitly illustrates the sequence stratigraphic evolution of the Colville foreland basin. In particular, the recognition of regressive and transgressive successions, major flooding surfaces, and subaerial unconformities help to subdivide mappable units and document relative sea level fluctuations that influenced the stratigraphic architecture.

The combination of bedrock mapping, 2D seismic profile interpretation, and well control also helped to constrain structural geometries at depth and the continuity of structures at the surface in areas where little outcrop exists. Deformation in the map area is entirely thin-skinned, and the style and concentration of deformation was heavily influenced by the relative strength of the prograding sedimentary packages. Hydrocarbon occurrences concentrated in sandstones near many of the anticlinal crests in the map area suggest that thermal maturation and hydrocarbon migration occurred during, or after, growth of these structures, possibly indicating the area may host untested structural traps.

New interpretation of existing apatite fission-track data from three map area wells indicate maximum burial of strata occurred between latest Cretaceous to late Paleocene-middle Eocene time. Apparent cooling at $\sim 60-50,45$, and possibly $34 \mathrm{Ma}$ is nearly identical to cooling episodes interpreted as contractional events elsewhere in the east-central foothills and northeastern Brooks Range. However, estimates of structural exhumation inferred from the cross section substantially underrepresent the magnitude of denudation suggested by AFT data in two out of three wells analyzed. Results and interpretations presented in this report suggest that widespread cooling in the Brooks Range and its foreland basin has involved elements of both denudation above structurally-thickened crust, and uplift of the foreland basin in the apparent absence of upper crustal thickening.

\section{DESCRIPTION OF MAP UNITS}

\section{SURFICIAL DEPOSITS}

ACTIVE FLOODPLAIN ALLUVIUM (Qal) — Poorly to well sorted, rounded to subangular, silty to coarse sand and polymictic gravel. Locally well stratified. Clasts include sandstone, silt, and shale derived from local bedrock sources, as well as reworked material from glacial deposits with sources in the Brooks Range to the south. Deposited by the action of modern streams and includes active channel deposits, floodplains, and terraces (Reger and others, 2008). Subject to periodic inundation by modern streams during flooding events and commonly contains numerous abandoned channels (Reger and 
others, 2008). Boulders are present locally, probably as lag from drift and outwash deposits. Along Toolik River, alluvial deposits are typically overlain by ice-rich silt.

GLACIAL OUTWASH (QTo) - Moderately to well sorted, clast supported, massive to weakly stratified, rounded to subangular, polymictic sandy pebble-cobble gravel deposited by the action of meltwater from glaciers with source areas in the Brooks Range to the south. Deposits are typically present as terraces that dissect drift and can be traced upvalley to moraine fronts (Waythomas, 1991; Hamilton, 1978). In smaller streams, especially those that are underfit, outwash occurs as low terraces or valley-bottom deposits. Along the Toolik, Sagavanirktok, and Ivishak rivers, deposits are commonly preserved as elevated terraces. Outwash terraces are discontinuous to continuous, with younger deposits typically being more continuous. Older outwash surfaces are generally more modified by colluvial processes than younger ones, and are commonly blanketed by ice-rich silt with abundant thaw lakes and well-developed patterned ground.

UNDIFFERENTIATED GLACIAL DRIFT AND COLLUVIUM (QTgd)—Poorly sorted, non-stratified boulder- and pebble-cobble gravel, generally matrix supported, containing abundant rounded to subangular clasts that may be striated and faceted. Clasts include sandstone, limestone, and shale. Locally includes moderately-well-sorted sand and gravel. Includes material of both glacial and non-glacial origin. In formerly glaciated areas, large cobbles to boulders of conglomerate and sandstone from the Kanayut Formation commonly protrude from the surface (Hamilton, 1986). The number of boulders on the surface and the degree of protrusion can be indicative of age, with older deposits having a lower density of visible boulders with less protrusion.

Younger glacial drift is characterized by hummocky topography and easily identifiable narrow moraines with steep moraine fronts (Hamilton, 1978, 1986). Kettle lakes are typically steep sided and show only slight modification by colluvial processes.

Older glacial drift is characterized by gently rolling topography extensively modified by colluvial and periglacial processes. Thaw lakes are commonly present with shorelines more modified by colluvial processes than those of the younger deposits. Many depressions contain ice-rich silt. Older moraine surfaces are broad with low-angle moraine fronts (Hamilton, 1986), and streams typically exhibit horsetail drainage patterns related to spring snowmelt or are beaded due to the abundance of ice-rich silt (Kreig and Reger, 1982).

In northern areas beyond the foothills where the origin of the drift is uncertain, periglacial features are common and colluvial processes dominate. Morainal features are not identifiable and polygonal lakes and low-angle slopes containing ice-rich silt characterize the surface. Streams in these areas are commonly poorly integrated.

Colluvial deposits are commonly associated with older glacial drift and outwash. Areas of widespread colluvium are characterized by the presence of solifluction lobes, colluvial fans, and slopewash deposits. Colluvial deposits are common along and near the base of bedrock and glacial drift slopes, especially in poorly drained areas.

EOLIAN DEPOSITS (Qe) (Stevens and others, 2003) - Chiefly ice-rich, well sorted, massive to finely bedded sand, silt, and clay deposits of eolian origin, modified by colluvial processes. Complex stratigraphy includes retransported eolian materials, and deposits in thermokarst basins and lakes. Deposits form a blanket over most of the broad, low-gradient region in the northern part of the map area, thinning to the south against the higher elevation Brooks Range foothills.

\section{BEDROCK DEPOSITS}

SAGAVANIRKTOK FORMATION (Gryc and others, 1951; Detterman and others, 1975; revised by Mull and others, 2003) (Paleogene)-Poorly consolidated pebble to cobble conglomerate, fine- to coarse-grained sandstone, siltstone, mudstone, and lignite. The type locality at Franklin Bluffs along the east side of the Sagavanirktok River constitutes an incomplete section of the unit. Regionally, the unit encompasses a broad range of nonmarine to shallow marine facies, reaching thicknesses that locally exceed 2,400 m (7,875 ft) in wells in the Camden Bay area offshore of northeastern Alaska. The Sagavanirktok grades northeastward into slope and basin facies of the younger parts of the Canning Formation. The formation is now divided into four members, thought to represent progradational sequences. These comprise coarse fluvial clastic deposits near the base that grade distally and upsection into carbonaceous siltstone, bentonitic mudstone, and coal (Mull and others, 2003). In and near the map area, the formation consists exclusively of nonmarine deposits. Only the basal Sagwon Member (Tss) is exposed in the map area; subcrop of the White Hills Member (Tsw) is shown in the far northwestern corner of the map area.

WHITE HILLS MEMBER (Tsw) (late Paleocene[?] to early Eocene)-Poorly consolidated, white-weathering pebble to boulder conglomerate and pebbly sandstone that form excellent outcrops in the lower part of the White Hills Member at a meander bend on the Toolik River a few hundred meters north of the northern map boundary. These exposures were designated 
by Mull and others (2003) as the reference section for the basal White Hills Member to supplement observations at the type section located in the northwestern White Hills. Clasts include light brownish-gray quartzite; black, brown, gray, light green, tan, and cream-colored chert; vein quartz; common white to beige leached tuff; deeply altered plutonic or gneissic rocks; local cobbles and boulders of quartz-mica schist; and local concentrations of fusain (charcoal) clasts. The quantity of volcanic clasts and the presence of plutonic and metamorphic clasts distinguish conglomerate of the White Hills Member from older conglomeratic units. Pebbles and cobbles greatly outnumber boulders. Conglomerates are dominated by low- to

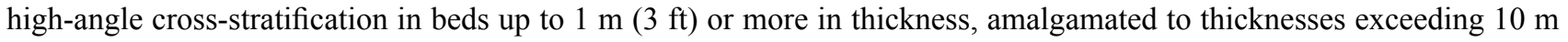
$(33 \mathrm{ft})$. Sandstones associated with the conglomerates form lenticular bodies with steeply dipping cross-stratification that suggests generally east-directed currents. Bedding is locally marked by concretionary beds of sideritized mudstone, which also occurs as rare, angular clasts up to boulder size in the conglomerates; this observation is consistent with scour and remobilization of early-formed siderite, and high-capacity flow events. The lower contact is not exposed, but is thought to be a sequence boundary (Mull and others, 2003) with the basal conglomeratic beds overlying bentonitic mudstone, lignite, and clinkers of the upper part of the Sagwon Member (Tss). Brown-weathering silty mudstones containing thin, discontinuous lignite beds are exposed below the sharp, apparently unconformable upper contact south of Franklin Bluffs. Thickness of the White Hills Member is not constrained by outcrop information; Mull and others (2003) estimated it may be as thick as $800 \mathrm{~m}$ ( 2,600 ft). The late Paleocene (?) to early Eocene age inferred by Mull and others (2003) is based on palynological data in the underlying Sagwon Member in the eastern White Hills, and from the top of the member in the Franklin Bluffs area (Frederiksen and others, 1996).

SAGWON MEMBER (Tss) (late Paleocene)-Poorly consolidated light gray to white, locally pink-orange-weathering pebble to cobble conglomerate, medium-grained to pebbly sandstone, siltstone, claystone, and coal. Quartzose and chert-rich sandstones and conglomerates dominate the base of the member at the type section in the area of VABM Gard at Sagwon Bluffs on the Sagavanirktok River. Clasts consist mainly of vein quartz, black to gray fresh chert, white tripolitic chert, and light gray quartzitic sandstone, with subordinate varicolored chert. Low-angle scour-and-fill stratification is pervasive in crudely-defined conglomerate beds $20-50 \mathrm{~cm}(8-20$ in) thick, amalgamated into packages $3-10 \mathrm{~m}(10-33 \mathrm{ft})$ thick. Conglomerates are interspersed with and truncate local beds of trough cross-stratified, medium-grained to conglomeratic sandstone up to $50 \mathrm{~cm}$ (20 in) thick. Collectively the basal interval is interpreted as braided fluvial deposits. Discontinuous outcrops in cutbanks of the Toolik River in the northwestern part of the map area appear to extend higher in the stratigraphic section and contain larger proportions of sandstone and finer-grained lithologies. Well developed stream-scale channels, sigmoidal cross-bedded sandstone, planar cross-stratified conglomerate, and thin- to medium-bedded sandstone, siltstone, carbonaceous mudstone, and local coal in this part of the Sagwon Member are considered likely to have been deposited by meandering fluvial systems. As revised by Mull and others (2003), the basal contact of the Sagwon Member is a sharp, apparently unconformable surface separating the overlying white-weathering conglomerates from the underlying coal, bentonite, carbonaceous mudstone, siltstone, and light-olive- to tan-weathering salt-and-pepper sandstone of the Prince Creek Formation. Thickness of the Sagwon Member is unknown from outcrop data; Mull and others (2003) speculated it may exceed $900 \mathrm{~m}(2,950 \mathrm{ft})$. Tentative picks in the Bush Federal 1 well correspond to a thickness of $220 \mathrm{~m}$ ( $722 \mathrm{ft})$ in the measured depth interval $\sim 832-612 \mathrm{~m}(\sim 2,730-2,008 \mathrm{ft})$ (fig. 4). The late Paleocene(?) age of the Sagwon Member as revised by Mull and others (2003) is based on palynological data in the eastern White Hills reported by Frederiksen and others (1996).

PRINCE CREEK FORMATION (Gryc and others, 1951; Brosgé and Whittington, 1966; revised by Mull and others, 2003) (Upper Cretaceous, Campanian to Paleocene) - Weakly consolidated to friable, light-olive-brown-weathering, fine- to coarse-grained and pebbly sandstone, conglomerate, siltstone, carbonaceous mudstone, bentonite, and coal. Strata at the type locality on Prince Creek west of Umiat and at Tuluvak Bluffs were reassigned to the Tuluvak Formation by Mull and others (2003), who designated outcrops on the Colville River bluffs downstream from the confluence of the Anaktuvuk River as exposures typical of the lower part of the revised Prince Creek Formation. The Prince Creek Formation is the dominantly nonmarine equivalent of the mainly marine Schrader Bluff Formation; together they constitute the largely progradational topset strata equivalent to slope and basin deposits of the older portions of the Canning Formation. Due to the distal interfingering with marine rocks, the thickness of the Prince Creek Formation is highly variable on a regional scale, and generally decreases toward the east. The complete thickness of the Prince Creek Formation in the map area has not been measured, but pending additional information, it is tentatively picked with a thickness of $385 \mathrm{~m}(1,265 \mathrm{ft})$ in the Susie Unit 1 well (measured depth interval $\sim 883-498 \mathrm{~m} \mathrm{[} \mathrm{2,897-1,634} \mathrm{ft])} \mathrm{drilled} 2 \mathrm{~km}(1.2 \mathrm{mi})$ north of the map area, and somewhat thinner in the Bush Federal 1 well farther north (fig. 4). The map area encompasses numerous excellent exposures of the upper part of the Prince Creek Formation (TKpc) and also includes a separate tongue of the lower part (Kpcl) along the Toolik River.

UPPER PART (TKpc) (Upper Cretaceous, Maastrichtian[?] to Paleocene)—Rock types are consistent with those described above, consisting of a broad range of poorly consolidated, light olive-brown-weathering sandstone, pebbly sandstone, siltstone, mudstone, carbonaceous shale, bentonite, and coal. The coarser sandstones are composed largely of quartz and 
black chert, have a salt-and-pepper appearance, commonly with carbonaceous fragments, leaf fossils, and silicified wood, are thin- to thick-bedded, commonly trough cross-bedded (meter-scale bedsets), and typically exhibit a blocky or upward-fining

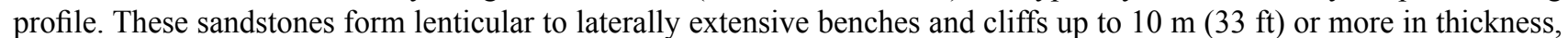
interpreted as having been deposited in generally east-flowing meandering river channels. Such units have good visible porosity and probably permeability, but are difficult to sample for porosity and permeability analysis due to their weak induration; some beds are heavily oil stained at several places south of VABM Gard at Sagwon Bluffs. Finer-grained strata and coals are generally thin- to medium-bedded, recessive weathering, and are best exposed along Sagwon Bluffs and in other smaller cutbanks adjacent to more resistant sandstones; these units are assigned to a variety of non-channelized nonmarine environments, including lacustrine, levee, crevasse splay, swamps, mires, and soil-forming environments (Flaig and van der Kolk, in press). Following the revision of mapping criteria by Mull and others (2003), the upper part of the Prince Creek Formation is distinguished from the lower part of the overlying Sagwon Member of the Sagavanirktok Formation by its brownish hues, bentonite, coal, smaller maximum clast diameter, lower clast concentration, and less diverse clast composition. The change in clast composition across the upper contact is consistent with the interpretation of Mull and others (2003) that it is probably a sequence-bounding unconformity. Nonmarine rocks at the base of the upper part of the Prince Creek Formation interfinger with marine facies of the upper part of the Schrader Bluff Formation. Where observed in outcrop above the west bank of the Ivishak River about $1.3 \mathrm{~km}$ south of VABM Hak, this contact is gradational over several meters. Scant palynomorph data (IRF Group, 2008, unpublished report) suggest the age of the main part of the Prince Creek Formation at Sagwon Bluffs ranges from late Campanian (?) to Paleocene. However, the questioned Campanian age call likely reflects reworked older pollen as it conflicts with Paleocene ages reported by Frederiksen and others (1996, 1998), some of which are from beds lower in the section. It also conflicts with Maastrichtian ages reported by Frederiksen and others (1998) in strata mapped with confidence here as uppermost Schrader Bluff Formation about $1 \mathrm{~km}(0.6 \mathrm{mi})$ south of VABM Hak on the Ivishak River. In the absence of more precise biostratigraphic or radiometric control from the lower part of the unit, its local age range is probably Maastrichtian to Paleocene.

LOWER TONGUE (Kpcl) (Upper Cretaceous, Campanian) - Light brown-, tan-, to buff-weathering very-fine- to fine-grained, salt-and-pepper textured sandstone, conglomerate, dark brown to black carbonaceous mudstone, thin coal beds, tuffaceous siltstone, bentonite, and tuff. Rocks are dominantly nonmarine and similar to the main part of the Prince Creek Formation (TKpc), but occur stratigraphically beneath the upper Schrader Bluff map unit (Ksbu) and overlie and intertongue with the middle Schrader Bluff map unit (Ksbm). The unit is distinguished from adjacent Schrader Bluff Formation by the brownish color, presence of conglomerates, coaly beds, fossil wood, leaves, and carbonaceous debris, and the absence of marine megafossils, marine ichnofossils, and wave-influenced sedimentary structures. In the map area, the lower tongue of the Prince Creek Formation is only exposed in intermittent ribs along the Toolik River on the flanks of the Kuparuk and Aufeis anticlines, where local interfingering with marine facies of the middle Schrader Bluff Formation is observed at sub-mappable scales. Thickness of the unit is probably at least $250 \mathrm{~m}$ (820 ft) (P. Flaig and D. van der Kolk, oral communication, 2009) where measured on the south flank of the Kuparuk anticline on the west side of the Toolik River. The age of the lower tongue of the Prince Creek Formation in the map area is bracketed as Campanian by palynomorph ages from the overlying upper Schrader Bluff Formation on the Toolik River (Molenaar and others, 1984) and in the Canning Formation (Kc) underlying laterally equivalent strata of the middle Schrader Bluff map unit (Ksbm) on Sagashak Creek (LePain and others, 2008b). $\mathrm{U} / \mathrm{Pb}$ analyses (results pending) from closely associated bentonite and tuff beds may yield more precise age constraints.

SCHRADER BLUFF FORMATION (Gryc and others, 1951; Whittington, 1956; Detterman and others, 1963; Brosgé and Whittington, 1966; revised by Mull and others, 2003) (Upper Cretaceous, Campanian to Maastrichtian[?]) - Light colored, marine sandstone, siltstone, bentonitic mudstone, bentonite, tuff, and shale. Sandstones and siltstones are typically tuffaceous, well consolidated, and contain abundant and diverse bivalve and trace fossil assemblages indicative of shelfal and shoreface environments. The formation was named for exposures at Schrader Bluff on the east side of the Anaktuvuk River in the Umiat Quadrangle, and was formerly divided into three members, in ascending order: the Rogers Creek, Barrow Trail, and Sentinel Hill Members. Due to generally poor exposures in the Umiat region, the lower and upper members were assigned subsurface type sections in the Gubik Test 1 and 2 and the Sentinel Hill Core Test 1 wells, respectively. The type section for the middle member of the formation is located 5-8 km (3.1-5 mi) northeast of Umiat Mountain in bluffs along the Colville River. The Schrader Bluff Formation represents dominantly shallow marine deposits that interfinger westward with dominantly nonmarine beds of the Prince Creek Formation and give way to the east to slope and basin deposits of the lower Canning Formation. Collectively, these units make up one of the low-order Brookian Sequence progradational cycles that fill the Colville foreland basin, but two widely correlatable internal surfaces (a lower sequence boundary and an upper flooding surface) divide the Schrader Bluff into lower, middle, and upper parts (fig. 1; Decker, 2007). This regional subdivision is not equivalent to the original three named members from the Umiat area, all of which represent only the lower Schrader Bluff Formation in the nomenclature used here (Decker, 2007; see also Flores and others, 2007a, 2007b). The lower part of the formation overlies the Tuluvak Formation west of the map area, and comprises shaly bentonitic mudstones, 
siltstones, tuffs, and lesser sandstone. Well and seismic correlations indicate the lower Schrader Bluff Formation is absent in the map area, where time-equivalent strata consist of slope and basin facies of the Canning Formation. The Schrader Bluff Formation is represented in the Sagavanirktok River area by the middle (Ksbm) and upper (Ksbu) map units; they reach a combined thickness of about 1,400 m (4,600 ft) in the Susie Unit 1 well a short distance to the north (fig. 4).

UPPER PART (Ksbu) (Upper Cretaceous, Campanian to Maastrichtian[?])—Rocks of the upper Schrader Bluff Formation in the Sagavanirktok River area include light greenish-gray to tan, well-sorted, medium- to thick-bedded, very fine- to fine-grained tuffaceous sandstone; dark olive-gray, well-sorted, thin-bedded to laminated, silty to very-fine-grained argillaceous sandstone; dark brown to gray siltstone, mudstone, and shale; and local beds of tuff and bentonite. Sandstones are composed of quartz, chert, and lithic grains, are mostly noncalcareous, and are well indurated. Centimeter-scale pyrite nodules with rusty orange-weathering haloes are common. Shale and mudstone near the base of the upper Schrader Bluff give way upward to a sandier succession organized into stacked coarsening- and thickening-upward parasequences 10-25 $\mathrm{m}(33-82 \mathrm{ft})$ thick. Sandstones in the upper parts of parasequences are typically medium- to thick-bedded, commonly with hummocky and swaley cross-stratification, and are frequently capped by sharp transgressive surfaces marked by a grit lag or shell hash. Bioturbation ranges from scant to intense, with Schaubcylindrichnus, Asterosoma, Rhizocorallium, Macaronichnus, Teichichnus, Diplocraterion, Planolites, Rosellia, and Paleophycus heberti (formerly Terebellina) among the most characteristic traces, consistent with deposition in shallow-water settings ranging from shoreface or proximal delta front to offshore environments. The general upward increase in sand content and grain size in the upper part of the Schrader Bluff Formation reflects a long aggradational and progradational history following the major transgressive flooding event that halted deposition of the middle Schrader Bluff (unit Ksbm) and the lower tongue of the Prince Creek Formation (unit $\mathrm{Kpcl}$ ). Except for a few relatively continuous exposures along cutbanks and bluffs of the larger drainages, the most resistant sandstones of the upper Schrader Bluff unit form tundra-covered ridges with subtly expressed rubble traces. Finer-grained intervals, particularly the bentonitic mudstones (containing a maximum flooding surface) near the base of the unit, tend to form stream valleys and recessive slopes that contrast with the more competent sandy strata (representing maximum regression) near the top of the underlying middle Schrader Bluff map unit. Distinguishing between the upper and middle Schrader Bluff Formation map units can be difficult in isolated exposures; mapped contacts are mostly approximations based on a combination of criteria including topographic expression, stratigraphic context relative to the overlying, underlying, and laterally equivalent map units, and surface extrapolations of horizons interpreted in seismic data. The transgressive basal contact is poorly exposed, and may be gradational over several meters or tens of meters. Where the upper contact is observed in outcrop above the west bank of the Ivishak River about $1.3 \mathrm{~km}$ south of VABM Hak, marine rocks of the upper Schrader Bluff Formation grade into the overlying nonmarine facies of the Prince Creek Formation over several meters. On the north limb of the Kuparuk anticline along the Ivishak River near the east edge of the map area, a measured section of the most continuous exposures of the upper Schrader Bluff Formation yields an incomplete thickness of more than $830 \mathrm{~m}(2,730 \mathrm{ft})$ (D. LePain, oral communication, 2009), but the upper and lower contacts are not exposed. About 5 mi $(8 \mathrm{~km})$ downstream near VABM Hak, the Echooka Unit 1 well (fig. 4) drilled a vertical (apparent) thickness of more than 1,950 $\mathrm{m}(6,070 \mathrm{ft})$ of the upper Schrader Bluff Formation, but beds near the surface location dip 30-50 degrees; the actual subsurface stratigraphic thickness is thus undoubtedly thinner, but lacking dip meter data, the true thickness is not well constrained. Perhaps the most reliable local thickness estimate for the upper Schrader Bluff comes from just north of the map area, where the Susie Unit 1 well (fig. 4) penetrated a subhorizontal section approximately $1,147 \mathrm{~m}(3,760 \mathrm{ft})$ thick (measured depth interval 883-2,030 m [2,897-6,661 ft]). Constraints on the age of the upper Schrader Bluff Formation in the map area are provided by Campanian palynomorphs on the south flank of the Kuparuk anticline along the Toolik River (Molenaar and others, 1984) and by late Campanian to possibly Maastrichtian Ar/Ar ages (70.8 $\pm 0.9 \mathrm{Ma}$ to $74.4 \pm 1.7 \mathrm{Ma}$; D. LePain, unpublished data) and a late Campanian U/Pb age (72.3 $\pm 0.7 \mathrm{Ma}$; M. Wartes, unpublished data) in the upper part of the unit on the north flank of the Kuparuk anticline along the Ivishak River.

MIDDLE PART (Ksbm) (Upper Cretaceous, Campanian)_-The middle Schrader Bluff Formation in the Sagavanirktok River area is similar in many respects to the upper Schrader Bluff map unit. Lithology varies with stratigraphic position. The lower part of the map unit consists mainly of darker, commonly heterolithic strata, including medium gray to olive, bioturbated or planar- to starved-ripple-laminated mudstone and siltstone, interbedded with fine-grained, thin- to medium-bedded, locally lenticular (scour filling) sandstone, locally carbonaceous and/or conglomeratic with pebbles and granules of black chert and vein quartz; outsized clasts of black chert interpreted as dropstones up to $6 \mathrm{~cm}$ diameter are locally common in both sandstone and finer-grained rocks. Upper exposures contain light greenish-gray- to tan-colored, medium- to thick-bedded, well-sorted, very-fine- to medium-grained sandstone; sandstones are composed of quartz, chert, and lithic grains, and are well indurated. Coarsening- and thickening-upward parasequences are common and contain hummocky and swaley crossstratified sandstone capped by knobby, bioturbated beds and grit or shell lags. The unit contains numerous 1 - to 5-cm-thick bentonite seams and well-indurated tuff beds approaching $1 \mathrm{~m}$ thick where interfingered with the lower tongue of the Prince Creek Formation (unit Kpcl) on the Toolik River. Megafossils consist of locally abundant equant and elongate bivalves, 
with local Turitella gastropod molds. Bioturbation ranges from scant to intense, with Schaubcylindrichnus, Asterosoma, Rhizocorallium, Macaronichnus, Diplocraterion, Planolites, Thalassinoides, Phycosiphon, and Helminthopsis among the most characteristic traces, consistent with deposition in shallow-water settings ranging from shoreface or proximal deltaic settings to offshore environments. Sandstones in the upper part of the unit tend to form dip-slopes at the top of hogbacks between less resistant strata of the underlying Canning Formation and the overlying upper Schrader Bluff Formation. The lower contact of the middle Schrader Bluff map unit is considered gradational with the underlying Canning Formation in most parts of the map area. Except where overlain by a mappable thickness of the lower Prince Creek tongue, the upper contact of the middle Schrader Bluff is a transgressive flooding surface overlain by relatively condensed bentonitic mud-

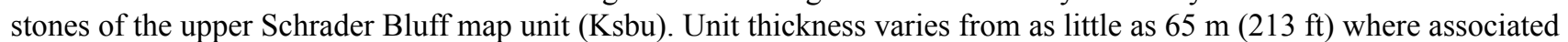
with the lower tongue of the Prince Creek Formation on the north limb of the Kuparuk anticline along the Toolik River to as much as $292 \mathrm{~m}$ (958 ft) in the Susie Unit 1 well (measured depth interval 2,030-2,322 m [6,661-7,620 ft]) a short distance north of the map area (fig. 4). The age of the middle Schrader Bluff map unit in the map area is Campanian, bracketed by palynomorph ages from the overlying upper Schrader Bluff Formation on the Toolik River (Molenaar and others, 1984) and in the underlying Canning Formation on Sagashak Creek (LePain and others, 2008b). U/Pb analyses (results pending) from closely associated bentonite and tuff beds may yield more precise age constraints.

CANNING FORMATION (Kc) (Molenaar and others, 1987) (Upper Cretaceous, Santonian to Campanian) - The Canning Formation, although dominantly fine grained, consists of a wide range of lithologies including bentonite, tuff, shale, siltstone, lime mudstone, tuffaceous and lithic sandstones, and local conglomerate. The following description draws heavily from exposures along Sagashak Creek, where discontinuous outcrops offer the most complete view into the range of facies and their stratigraphic order (LePain and others, 2008a, 2008b). At Sagashak Creek, the base of the formation is complexly deformed by a more-than-20-m-thick (66-ft-thick) zone of disharmonic folds bounded above and below by undisturbed strata - a condition common in mass transport slump complexes. Regional well and seismic data provide evidence of potentially correlative mass wasting associated with a mid-Campanian unconformity (MCu; Decker, 2007), which in some areas represents the base of the Canning Formation. The lower part of the formation includes dark-gray-weathering, organic-rich clay shale and fissile to chippy siltstone interbedded with thin, brown- to light-gray-weathering, plane-parallel laminated, very fine sandstone beds. Rippled, orange-weathering tuffaceous sandstone and siltstone beds with local small, soft-sediment slump folds are associated with whitish-yellow bentonite seams and laminated gray- and reddish-brown-weathering silicified tuffs - the latter are locally strongly oil stained near the very base of the formation. Thin lime mudstone beds up to $30 \mathrm{~cm}$ (12 in) thick are present but rare. The significant contribution of air-fall volcanic material in this lower part of the formation imparts a conspicuous reddish-orange-weathering hue visible from a distance. The middle part of the formation, where exposed, includes interbeds of thin- to thick-bedded, tan-to-buff-weathering carbonaceous sandstone, light gray siltstone, and several poorly sorted pebble to cobble conglomerate beds up to $50 \mathrm{~cm}(20 \mathrm{in})$ thick. Thin- to medium-bedded sandstones exhibit subtle normal grading with abundant and diverse sole marks including loads, flutes, and grooves; bedding ranges from internally massive to plane laminated and rippled; carbonaceous particles and larger fragments are common on bedding planes. The conglomerate beds have up to $20 \mathrm{~cm}$ ( $8 \mathrm{in}$ ) of relief on scoured bases and include both intra- and extra-basinal clasts up to small cobbles; clast types include varieties of chert and siliceous mudstone, white vein quartz, tuff, shale, and orange-weathering sideritized (?) mudstone rip-ups. The upper part of the formation along Sagashak Creek includes a remarkably repetitive series of centimeter-scale beds of very-fine-grained, normally graded to plane-parallellaminated sandstone and siltstone; beds are laterally continuous and of uniform thickness, giving the outcrops a monotonous appearance. The uppermost part of the formation is more variable where exposed farther north on an unnamed creek near the hinge of the Kuparuk anticline, and includes bentonite and several thin conglomerate beds. A noteworthy but isolated conglomeratic outcrop in the southern part of the map is also tentatively assigned to the Canning Formation primarily based on clast composition, but its stratigraphic position in the unit is not known. This reddish-weathering knob is east of the Sagavanirktok River, in the immediate footwall of Ice Cut thrust. Approximately $10 \mathrm{~m}(4 \mathrm{ft})$ thick, the weakly stratified pebble conglomerate is poorly sorted, mostly clast supported, and includes lenticular interbeds of sandstone up to $50 \mathrm{~cm}$ (20 ft) thick; clasts are well rounded, up to $15 \mathrm{~cm}$ and include about 15 percent vein quartz, abundant chert and siliceous mudstone, and lesser fine-grained quartzite. The remainder of sedimentary facies observed in the map area are consistent with base-of-slope to slope settings dominated by sediment gravity flows ranging from unconfined dilute turbidity currents to higher density flows; the conglomerate beds may reflect submarine channel incision and filling. These interpreted depositional processes and settings are consistent with regional well and seismic correlations indicating that in this map area the Canning Formation represents deepwater clinoform deposits equivalent to the nonmarine and shallow-marine topsets of the Prince Creek and Schrader Bluff Formations (LePain and others, 2008a). The outcrops in the map area represent the westernmost (and oldest) examples of the Canning Formation exposed at the surface. The only megafossil known from this unit in the map area is the late Santonian to earliest Campanian bivalve Sphenoceramus patootensis (Mull, unpublished data) collected from the lower part of the formation on Sagashak Creek. Palynologic data support a Campanian age for most of the formation in this area (DGGS, unpublished data). LePain and others (2008b) calculated a thickness of approximately 
$1,300 \mathrm{~m}(4,265 \mathrm{ft})$ at Sagashak Creek, where direct measurement is complicated by long stretches of cover; the unit has a vertical thickness of $1,166 \mathrm{~m}(3,825 \mathrm{ft})$ in the Echooka Unit 1 well approximately $30 \mathrm{~km}(18.6 \mathrm{mi})$ to the north, where it represents the measured depth interval 2,312-3,478 m (7,585-11,411 ft) (fig. 4).

SEABEE FORMATION (Ks) (Gryc and others, 1951; Whittington, 1956; revised by Mull and others, 2003) (Upper Cretaceous, Cenomanian to Coniacian)-Strata assigned to the Seabee Formation in the map area are organized into packages dominated by either sandstone or mudstone. Sandstone is typically light gray to locally rusty-red-brown weathering, very fine to fine grained, and moderately indurated to slightly friable; weak to moderate oil odor is observed in the more friable examples. Mica and/or phyllitic rock fragments are locally abundant and readily apparent to the unaided eye. Sandstone beds are commonly internally massive with cryptic amalgamation surfaces that pass laterally into mudstone, indicating local scouring. Sedimentary structures locally include normal grading, plane-parallel lamination, parting lineation, flutes, grooves, ripples, and small-scale trough cross-stratification. Rip-up clasts of mudstone are concentrated in some beds. The best exposures of the sandstone packages are found discontinuously along Sagashak Creek near the core of the Aufeis anticline (LePain and others, 2008) and just downstream of the confluence of the Lupine and Sagavanirktok rivers. Uplands in the southeastern part of the map area, such as the prominent hilltop occupied by VABM Inter, exhibit rubble traces of resistant sandstone, consistent with the discrete sandstone/mudstone packaging recognized in better exposures along rivers and streams. Mudstone-dominated packages are rarely exposed and are inferred to underlie many covered intervals between resistant sandstone bodies; where observed, they consist of medium gray argillaceous siltstone, olive-gray chippy siltstone, and lesser green-gray fissile clay shale. An excellent exposure along the Lupine River approximately $1.6 \mathrm{~km}$ (1 mi) downstream of the trace of the Ice Cut thrust includes both a lower, mudstone-dominated interval and an upper, sandstonedominated interval; in the fine-grained facies, platy-weathering siltstone is finely intercalated with densely rippled, thin beds of very-fine sandstone and, rarely, thin bentonite seams; sandstone abundance and bed thickness increase dramatically above a scoured surface with $\sim 2 \mathrm{~m}$ ) $\sim 6.5 \mathrm{ft}$ of erosional relief. Granule and pebble conglomerate was observed at one locality along the west bank of the Sagavanirktok River, about $1.6 \mathrm{~km}(1 \mathrm{mi})$ north of the Ice Cut thrust; clasts include abundant white tripolitic chert in addition to brown, gray, and black fresh chert and silicified mudstone. Based principally on the sedimentary structures in the sandstone, the Seabee Formation is interpreted as dominantly sediment gravity flow deposits; local evidence for tractive sediment transport and scouring suggest deposition via turbulent flows. A deepwater setting is suggested by the lack of bioturbation and supported by regional subsurface interpretations that indicate the map area lies basinward of the Turonian shelf edge (Houseknecht and Schenk, 2005). The deepwater depositional setting and facies in the map area contrast with those of the Seabee Formation described in previous outcrop studies to the west where the unit was deposited in shallower water on the shelf constructed by the underlying Nanushuk Formation (see summary in Mull and others, 2003). The deepwater Seabee Formation of the map area may more closely resemble the Cenomanian to Turonian interval drilled in the Tarn-Meltwater area to the northwest. However, the locally abundant and conspicuous mica flakes and phyllitic(?) rock fragments appear unique to the eastern foothills; this is one of several factors that suggests the unit in the map area had more direct and persistent input from provenance areas in the ancestral Brooks Range than correlative Seabee intervals farther northwest. Age control in the map area is provided by the early Turonian bivalve Mytiloides labiatus (Mull, unpublished data) and the uppermost Cenomanian to early Turonian ammonite Scaphites delicatulus Warren (W. Elder, written communication, 2008). The complete thickness of the Seabee Formation is not adequately constrained from outcrop data; the Echooka Unit 1 well penetrated a vertical thickness of $315 \mathrm{~m}(1,033 \mathrm{ft})$ in the measured depth interval 3,265-3,580 m (10,713-11,745 ft) (fig. 4).

TOROK FORMATION (Kt) (Gryc and others, 1951; Patton, 1956) (middle Cretaceous, Albian to Cenomanian) - The Torok Formation is organized into discrete packages dominated by either sandstone or silty mudstone. Sandstone is indurated, lithic, light to medium olive-gray- or light brown- to tan-weathering, dominantly fine to medium grained, and moderate to poorly sorted. Mica and phyllitic(?) rock fragments are locally conspicuous. Sandstone beds are typically decimeters thick and amalgamated along obscure bed boundaries; most are internally massive, although subtle normal grading occurs, particularly in coarser-grained examples with granules at the base; sole marks on the base of sandstone beds include flutes, grooves, and various load features. Mud rip-ups and carbonaceous debris are locally abundant. Convolute lamination is present locally; low-angle and possible small-scale trough cross-stratification are locally developed, but subordinate to diffuse, plane-parallel lamination is also present. Ripple cross-stratification ranges from rare to ubiquitous and is most common at the top of beds. This assemblage of sedimentary structures is consistent with deposition from medium- to high-concentration sediment gravity flows, probably in deep water. Mudstone facies are not commonly exposed, but where observed are moderately hard siltstone and silty shale ranging from monotonous medium gray to brownish maroon with a conspicuous iridescent-purple-weathering sheen. Silty shales are locally punctuated by densely rippled, very-thin-bedded, very-fine-grained sandstone interpreted as the product of dilute turbidity currents. Bentonite and tuff are rare although local "popcorn" weathering suggests a possible volcanic component in recessive intervals. The stacking of the resistant sandstone and recessive silty facies is well expressed near the hinge of the Lupine anticline on the Sagavanirktok River just 
downstream of the confluence with the Lupine River. The sandstone packages appear to be sharp-based and generally fine upward over a thickness of 5 to $15+\mathrm{m}(16$ to $50+\mathrm{ft})$. The juxtaposition of these facies can also be seen in the steeply dipping strata at the Ice Cut (fig. 2), an easily accessible location along the Dalton Highway (Mull and Harris, 1989) just south of the mapped position of the Ice Cut thrust. The discrete occurrence of sandstone-dominated facies can also be inferred from the intermittent pattern of rubble-crop traces in the southernmost part of the map area, east of the Sagavanirktok River. Thick sandstone-dominated zones also cap resistant, mesa-like knobs, especially in the southeasternmost part of the map area. This grain-size partitioning is consistent with the log character in the Lupine Unit 1 well and also mirrors that of the correlative Gilead sandstone in the Ivishak River and Gilead syncline areas just east of the map area (Decker and others, 2008). Based on the overall sedimentology, stacking pattern, and context in the basin, the unit is interpreted to represent a base-of-slope or basin-floor setting where migrating sandstone lobes or channels are interspersed with off-axis, finer-grained facies. Limited paleocurrent data from sole marks and ripples indicate northward and north-northeastward paleoflow. The Torok Formation was defined along the upper Chandler River, considerably southwest of the map area (Gryc and others, 1951). The inferred depositional settings for the type Torok Formation in the inner Brooks Range foothills are similar to that interpreted above, although the thickness of the sandstone packages and overall sand:shale ratio are generally higher in the map area. Given the east-northeast progradation of this interval observed in regional seismic data (for example, Houseknecht and others, in press), much of the Torok Formation in the map area is likely to be younger than exposures of the formation to the west and south. Outcrops near the top of the formation along the Sagavanirktok River near its confluence with the Lupine River probably include Torok of Cenomanian age. This younger age assignment is not constrained by existing biostratigraphic interpretations, but is supported by the presence of bentonitic shales and a subtly lighter gray-weathering character inferred to be the result of increased tuffaceous material characteristic of the Upper Cretaceous (LePain and others, 2002). In addition, similar facies along the Ivishak River and high in the section at Gilead syncline have yielded the Cenomanian bivalve Inoceramus Dunveganensis (Reifenstuhl, 1991; W. Elder, written comms., 2008, 2009). South of the Ice Cut thrust, the Torok Formation is interpreted to be largely middle to late Albian, representing the lower and/or middle parts of the formation. This assignment is supported by the occurrence of the late middle Albian ammonite Gastroplites sp. aff. G. kingi McLearn (W. Elder, written communication, 2008), and a middle to late Albian pelecypod fauna including Inoceramus anglicus Woods and Inoceramus cf. I. kedroviensis Pergament (W. Elder, written communication, 2009). The total thickness of the formation is not known from outcrops in the map area. We tentatively interpret the slightly deviated

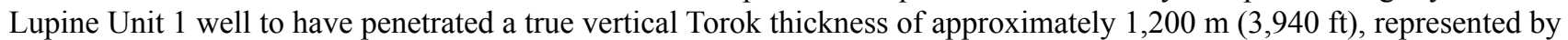
the measured depth interval 2,109-3,337 m (6,920-10,950 ft). This thickness includes an upper 840-m-thick (2,756-ft-thick) interval with a high proportion of sandstone relative to mudstone, and a basal Brookian mudstone interval approximately 360 $\mathrm{m}(1,180 \mathrm{ft})$ thick. East of the map area, Torok-equivalent strata of the Gilead succession are at least $850 \mathrm{~m}(2,780 \mathrm{ft})$ thick (Reifenstuhl, 1991), with striking similarities in thickness and stratigraphic architecture to the sandier upper section in the Lupine Unit 1 well. Both the Torok Formation and the partially age-equivalent Gilead succession thin dramatically to the north, probably by a combination of distal taper of the clinoform slope wedge (Houseknecht and others, in press) and onlap of basinal strata onto the north flank of the Colville basin (Decker and others, 2008); equivalent strata are essentially absent due to nondeposition at the Echooka Unit 1 well in the northeastern part of the map area, and have not been recognized in Neocomian through Upper Cretaceous age exposures on the Echooka River northeast of Gilead syncline.

\section{ACKNOWLEDGMENTS}

We dedicate this map to the late Rocky Reifenstuhl, whose countless mapping traverses contributed significantly to our present understanding of North Slope geology. We trust the many stories of his legendary energy will continue to inspire the next generation of Alaska geologists. He is greatly missed.

Outcrop stratigraphic work by David LePain and Russ Kirkham contributed to our understanding key stratigraphic relationships in the map area. Valuable discussions with a number of colleagues greatly helped refine our views of the local and regional geology, including David LePain, David Houseknecht, Wesley Wallace, Peter Flaig, Dolores Van der Kolk, Dick Garrard, and Gregory Wilson. University of Alaska Fairbanks students Steve Polkowski, Dolores Van der Kolk, Jake Mongrain, and Peter Flaig all helped with field logistics at some point in the project. We thank Dick Garrard for persistently pushing us forward toward completion of this map, Greg Wilson and Wes Wallace for timely and thoughtful reviews, and Gil Mull for impressing upon us the potential stratigraphic importance of the area and for many insightful conversations and suggestions while planning the mapping project and when considering the final version of the map. Helicopter pilot Tom "Rat" Ratledge expertly transported us throughout the map area and back to camp safely, often pointing out an unnoticed outcrop in the process. Completion of the map was made possible by funding from a variety of sources, including operating and capital improvement project funds from the State of Alaska (Division of Geological \& Geophysical Surveys and Division of Oil \& Gas), and the STATEMAP program of the National Cooperative Geologic Mapping Program administered by the U.S. Geological Survey (award 08HQAG0051). Fieldwork was also supported 
by substantial contributions from companies involved in the Alaska oil and gas industry. Recent sponsors (2007 and 2008) included Anadarko Petroleum Corp., BG Alaska, BP, Chevron, ConocoPhillips Alaska Inc., ENI, Petro-Canada, Pioneer Natural Resources, Repsol YPF Exploration and Production Co., Shell International Exploration and Production Co., and Talisman Energy Inc.

\section{REFERENCES}

Beaumont, Chris, 1981, Foreland basins: Geophysical Journal of the Royal Astronomical Society, v. 65, no. 2, p. 291-329.

Bird, K.J., and Molenaar C.M., 1992, The North Slope foreland basin, in Macqueen, R.W., and Leckie, D.A., eds., Foreland basins and foldbelts: American Association of Petroleum Geologists Memoir 55, p. 363-393.

Blythe, A.E., Bird, J.M., and Omar, G.I., 1996, Deformational history of the central Brooks Range, Alaska-Results from fission-track and ${ }^{40} \mathrm{Ar} /{ }^{39} \mathrm{Ar}$ analyses: Tectonics, v. 15, no. 2 , p. $440-455$.

Brosgé, W.P., and Whittington, C.L., 1966, Geology of the Umiat-Maybe Creek region, Alaska, with Heavy-mineral studies of the Umiat-Maybe Creek region, by R.H. Morris: U.S. Geological Survey Professional Paper 303-H, p. 501-638.

Burns, W.M., Hayba, D.O., Rowan, E.L., and Houseknecht, D.W., 2007, Estimating the amount of eroded section in a partially exhumed basin from geophysical well logs - An example from the North Slope: Studies by the U.S. Geological Survey in Alaska, 2005, U.S. Geological Survey Professional Paper 1732-D, 18 p.

Chmielowski, R.M., Wallace, W.K., and O'Sullivan, P.B., 2000, Duplex structure and Paleocene displacement of the Toyuk thrust zone near the Dalton Highway, northcentral Brooks Range, in Pinney, D.S., and Davis, P.K., eds., Short Notes on Alaska Geology 1999: Alaska Division of Geological \& Geophysical Surveys Professional Report 119B, p. 11-31, doi:10.14509/2684.

Cole, F., Bird, K.J. Toro, J., Roure, F., O’Sullivan, P.B., Pawlewicz, M., and Howell, D.G., 1997, An integrated model for the tectonic development of the northern Brooks Range and Colville basin $250 \mathrm{~km}$ west of the Trans-Alaska Crustal Transect: Journal of Geophysical Research, v. 102, p. 20,645-20,684.

Daly, R.J., Jolley, D.W., and Spicer, R.A., 2011, The role of angiosperms in Palaeocene arctic ecosystems-A palynological study from the Alaska North Slope: Palaeogeography, Palaeoclimatology, Palaeoecology, v. 309, p. 374-382.

Decker, P.L., 2007, Brookian sequence stratigraphic correlations, Umiat Field to Milne Point Field, west-central North Slope, Alaska: Alaska Division of Geological \& Geophysical Surveys Preliminary Interpretive Report 2007-2, 19 p., 1 sheet, doi:10.14509/15758.
Decker, P.L., Wartes, M.A., Wallace, W.K., Houseknecht, D.W., Schenk, C.J., Gillis, R.J., and Mongrain, Jacob, 2008, Stratigraphic and structural investigations in the Ivishak River and Gilead Creek areas-Progress during 2007, in Wartes, M.A., and Decker, P.L., eds., Preliminary results of recent geologic field investigations in the Brooks Range Foothills and North Slope, Alaska: Alaska Division of Geological \& Geophysical Surveys Preliminary Interpretive Report 2008-1F, p. 55-83, 1 sheet, doi:10.14509/16089.

Detterman, R.L., Bickel, R.S., and Gryc, George, 1963, Geology of the Chandler River region, Alaska: U.S. Geological Survey Professional Paper 303-E, p. 223-324.

Detterman, R.L., Reiser, H.N., Brosgé, W.P., and Dutro, J.T., 1975, Post-Carboniferous stratigraphy, northeastern Alaska: U.S. Geological Survey Professional Paper 886, 46 p.

Flaig, P.P., and van der Kolk, D.A., in press, Depositional environments of the Prince Creek Formation along the east side of the Toolik River, Sagavanirktok Quadrangle, North Slope, Alaska: Alaska Division of Geological \& Geophysical Surveys Preliminary Interpretive Report.

Flores, R.M., Myers, M.D., Houseknecht, D.W., Stricker, G.D., Brizzolara, D.W., Ryherd, T.J., and Takahashi, K.I., 2007a, Stratigraphy and facies of Cretaceous Schrader Bluff and Prince Creek Formations in Colville River Bluffs, North Slope, Alaska: U.S. Geological Survey Professional Paper 1748, 1 p.

Flores, R.M., Stricker, G.D., Decker, P.L., and Myers, M.D., 2007b, Sentinel Hill Core Test 1-Facies descriptions and stratigraphic reinterpretations of the Prince Creek and Schrader Bluff Formations, North Slope, Alaska: U.S. Geological Survey Professional Paper 1747, 31 p.

Frederiksen, N.O., Andrle, V.A.S., Sheehan, T.P., Ager, T.A., Collett, T.S., Fouch, T.D., Franczyk, K.J., and Johnson, M., 1998, Palynological dating of Upper Cretaceous to middle Eocene strata in the Sagavanirktok and Canning Formations, North Slope of Alaska: U.S. Geological Survey Open-File Report 98-471, 51 p.

Frederiksen, N.O., Sheehan, T.P., Ager, T.A., Collett, T.S., Fouch, T.D., Franczyk, K.J., and Johnson, M., 1996, Palynomorph biostratigraghy of Upper Cretaceous to Eocene samples from the Sagavanirktok Formation in its type region, North Slope of Alaska: U.S. Geological Survey Open-File Report 96-84, 44 p.

Galbraith, R.F., 1981, On statistical models for fission track counts: Journal of the International Association for Mathematical Geology, v. 13, no. 6, p. 471-478.

Galbraith R.F., and Laslett, G.M., 1993, Statistical models for mixed fission track ages: Nuclear Tracks and Radiation Measurements, v. 21, no. 4, p. 459-470.

Garrity, C.P., Houseknecht, D.W., Bird, K.J., Potter, C.J., Moore, T.E., Nelson, P.H., and Schenk, C.J., 2005, U.S. Geological Survey 2005 oil and gas resource assessment of the central North Slope, Alaska-Play maps and results: U.S. Geological Survey Open-File Report 2005-1182, 1 p. 
Geologic Materials Center (GMC), 1990, Apatite fissiontrack analysis of cuttings from the following 3 wells: Texaco Inc. Tulugak \#1 (1,600-16,472 ft); Forest Oil Co. Lupine Unit \#1 (1,000-13,500 ft); and Texaco Inc. East Kurupa Unit \#1 (900-12,695 ft): Alaska Division of Geological \& Geophysical Surveys Geologic Materials Center Data Report 149, 32 p, doi:10.14509/18986.

Grybeck, Donald, Beikman, H.M., Brosgé, W.P., Tailleur, I.L., and Mull, C.G., 1977, Geologic map of the Brooks Range, Alaska: U.S. Geological Survey Open-File Report 77-166-B, 2 sheets, scale 1:1,000,000.

Gryc, George, Patton, W.W., Jr., and Payne, T.G., 1951, Present Cretaceous stratigraphic nomenclature of northern Alaska: Washington Academy of Sciences Journal, v. 41 , p. $159-167$.

Hamilton, T.D., 1978, Surficial geologic map of the Philip Smith Mountains Quadrangle, Alaska: U.S. Geological Survey Miscellaneous Field Studies Map 879-A, 1 sheet, scale 1:250,000.

1986, Late Cenozoic glaciation of the central Brooks Range, in Hamilton, T.D., Reed, K.M., and Thorson, R.M., eds., Glaciation in Alaska-The geologic record: Anchorage, Alaska Geological Society, p. 9-49.

Houseknecht, D.W., and Schenk, C.J., 2005, Sedimentology and sequence stratigraphy of the Cretaceous Nanushuk, Seabee, and Tuluvak Formations exposed on Umiat Mountain, north-central Alaska, in Haeussler, P.J., and Galloway, J.P., eds., Studies by the U.S. Geological Survey in Alaska, 2004: U.S. Geological Survey Professional Paper 1709B, 18 p., 1 plate.

Houseknecht, D.W., Bird, K.J., and Schenk, C.J., 2009, Seismic analysis of clinoform depositional sequences and shelf-margin trajectories in Lower Cretaceous (Albian) strata, Alaska North Slope: Basin Research , v. 21, no. 5, p. 644-654.

Houseknecht, D.W., Bird, K.J., and O'Sullivan, Paul, 2011, Constraining the age and magnitude of uplift in the northern National Petroleum Reserve in Alaska (NPRA) - Apatite fission-track analysis of samples from three wells, in Dumoulin, J.A., and Dusel-Bacon, Cynthia, eds., Studies by the U.S. Geological Survey in Alaska, 2010: U.S. Geological Survey Professional Paper 1784-A, 21 p., 1 plate.

Howell, D.G., Bird, K.J., Huafu, Lu, and Johnsson, M.J., 1992, Tectonics and petroleum potential of the Brooks Range fold and thrust belt-A progress report, in Bradley, D.C., and Ford, A.B., eds., Geologic Studies in Alaska by the U.S. Geological Survey During 1990: U.S. Geological Survey Bulletin 1999, p. 112-126.

Hubbard, R.J., Edrich, S.P., and Rattey, R.P., 1987, Geologic evolution and hydrocarbon habitat of the "Arctic Alaska microplate": Marine and Petroleum Geology, v. 4, no. 1, p. 2-34.

Hubbard, T.D., in prep., Surficial-geologic map of parts of the Sagavanirktok and Toolik river drainages, northern Brooks Range foothills, Alaska: Alaska Division of
Geological \& Geophysical Surveys Report of Investigation 201x-xx , 1 sheet, scale 1:63,360.

Huffman, A.C., Jr., Ahlbrandt. T.S., Pasternack, I., Stricker, G.D., and Fox, J.E., 1985, Depositional and sedimentologic factors affecting the reservoir potential of the Cretaceous Nanushuk Group, central North Slope, Alaska, in Huffman, A.C., ed., Geology of the Nanushuk Group and related rocks, North Slope, Alaska: U.S. Geological Survey Bulletin 1614, p. 61-74.

Jordan, T.E., 1981, Thrust loads and foreland basin evolution, Cretaceous, western United States: American Association of Petroleum Geologists Bulletin, v. 65, no. 12, p. 2,506-2,520.

Keller, A.S., Morris, R.H., and Detterman, R.L, 1961, Geology of the Shaviovik and Sagavanirktok rivers region, Alaska: U.S. Geological Survey Professional Paper 303-D, p. 169-222, 5 plates.

Kreig, R.A., and Reger, R.D., 1982, Air-photo analysis and summary of landform soil properties along the route of the Trans-Alaska Pipeline System: Alaska Division of Geological \& Geophysical Surveys Geologic Report 66, 149 p., doi:10.14509/426.

Lathram, E.H., 1965, Preliminary geologic map of northern Alaska, U.S. Geological Survey Open-File Report 65-96, 2 sheets, scale 1:1,000,000.

LePain, D.L., Kirkham, R.A., and McCarthy,P.J., 2002, Shoreline to basin transition (?) in Albian-Cenomanian strata east of the Sagavanirktok River, Brooks Range foothills, Alaska [abst.]: AAPG Bulletin, v. 86, no. 6, p. $1,149-1,150$.

LePain, D.L., Kirkham, Russell, Gillis, R.J., and Mongrain, Jacob, 2008, Turonian-Campanian strata east of the transAlaska pipeline corridor, North Slope foothills, Alaska: Progress during the 2001-02 and 2007 field seasons, in Wartes, M.A., and Decker, P.L., eds., Preliminary results of recent geologic field investigations in the Brooks Range Foothills and North Slope, Alaska: Alaska Division of Geological \& Geophysical Surveys Preliminary Interpretive Report 2008-1G, p. 85-134, doi:10.14509/16090.

LePain, D.L., McCarthy, P.J., and Kirkham, Russell, 2009, Sedimentology and sequence stratigraphy of the middle Albian-Cenomanian Nanushuk Formation in outcrop, central North Slope, Alaska: Alaska Division of Geological \& Geophysical Surveys Report of Investigation 2009-1, v. 2, 76 p., 1 sheet, doi:10.14509/19761.

McMillen, K.J., and O'Sullivan, P.B., 1992, Tectonic and eustatic controls on Paleogene sequence stratigraphyBeaufort Sea, Alaska, and Canada, in Watkins, J.S., Zhiqiang, F., and McMillen, K.J., eds., Geology and geophysics of continental margins: American Association of Petroleum Geologists Memoir 53, p. 285-301.

Molenaar, C.M., 1983, Depositional relations of Cretaceous and lower Tertiary rocks, northeastern Alaska: American Association of Petroleum Geologists Bulletin, v. 67, p. $1,066-1,080$. 
Molenaar, C.M., Bird, K.J., and Kirk, A.R., 1987, Cretaceous and Tertiary stratigraphy of northeastern Alaska, in Tailleur, I.L., and Weimer, Paul, eds., Alaskan North Slope geology: Society of Economic Paleontologists and Mineralogists, Pacific Section, Book 50, v. 2, p. 513-528.

Molenaar, C.M., Bird, K.J., and Collett, T.S., 1986, Regional correlation sections across the North Slope of Alaska: U.S. Geological Survey Miscellaneous Field Studies Map 1907, 1 sheet.

Molenaar, C.M., Kirk, A.R., Magoon, L.B., and Huffman, A.C., 1984, Twenty-two measured sections of Cretaceous-lower Tertiary rocks, eastern North Slope, Alaska: U.S. Geological Survey Open-file Report 84-695, 21 p., 4 sheets.

Mooney, R., 2006, Apatite fission track analysis of cutting samples from the following six wells from the North Slope region, Alaska-Amethyst State \#1, Awuna \#1, Oumalik Test \#1, Susie Unit \#1, and West Kurupa \#1: Alaska Division of Geological \& Geophysical Surveys Geologic Materials Center Data Report 333, 61 p. doi:10.14509/19541.

Moore, T.E., Potter, C.J., O’Sullivan, P.B., Shelton, K.L., and Underwood, M.B., 2004, Two stages of deformation and fluid migration in the west-central Brooks Range fold and thrust belt, northern Alaska, in Swennen, R., Roure, F., and Granath, J.W., eds., Deformation, fluid flow, and reservoir appraisal in foreland fold and thrust belts: American Association of Petroleum Geologists Hedberg Series, no.1, p. 157-186.

Mull, C.G., and Harris, E.E., 1989, Road log from Chandalar Shelf (Mile 237.1) to Prudhoe Bay (Mile 414), in Mull, C.G., and Adams, K.E., eds., 1989, Bedrock geology of the eastern Koyukuk basin, central Brooks Range, and east-central Arctic Slope along the Dalton Highway, Yukon River to Prudhoe Bay, Alaska: Alaska Division of Geological \& Geophysical Surveys Guidebook 7, v. 1, p. 101-130, doi: $10.14509 / 24113$.

Mull, C.G., Houseknecht, D.W., and Bird, K.J., 2003, Revised Cretaceous and Tertiary stratigraphic nomenclature in the Colville basin, northern Alaska: U.S. Geological Survey Professional Paper 1673, 51 p.

Mull, C.G., Harris, E.E., Delaney, P.R., and Swenson, R.F., 2009, Geology of the Cobblestone Creek-May Creek area, east-central Brooks Range Foothills, Alaska: Alaska Division of Geological \& Geophysical Surveys Preliminary Interpretive Report 2009-5, 40 p., 1 sheet, scale 1:63,360, doi:10.14509/19661.

Murphy, J.M., O’Sullivan, P.B., and Gleadow, A.J.W., 1994, Apatite fission-track evidence of episodic Early Cretaceous to late Tertiary cooling and uplift, central Brooks Range, Alaska, in Thurston, D., and Fujita, K., eds., 1992 Proceedings, International Conference on Arctic Margins: U.S. Minerals Management Service Outer Continental Shelf Study 94-0040, p. 257-262.
Nelson, P.H., and Bird, K.J., 2005, Porosity-depth trends and regional uplift calculated from sonic logs, National Petroleum Reserve in Alaska: U.S. Geological Survey Scientific Investigations Report 2005-5051, 23 p.

O’Sullivan, P.B., 1996, Late Mesozoic and Cenozoic thermal-tectonic evolution of the North Slope foreland basin, Alaska, in Johnsson, M.J., and Howell, D.G., eds., Thermal evolution of sedimentary basins in Alaska: U.S. Geological Survey Bulletin 2142, p. 45-79.

O'Sullivan, P.B., 1999, Thermochronology, denudation and variations in palaeosurface temperature - A case study from the North Slope foreland basin, Alaska: Basin Research, v. 11, p. 191-204.

O’Sullivan, P.B., and Wallace, W.K., 2002, Out-of-sequence, basement-involved structures in the Sadlerochit Mountains region of the Arctic National Wildlife Refuge, Alaska-Evidence and implications from fission-track thermochronology: Geological Society of America Bulletin, v. 114, no. 11, p. 1,356-1,378.

O’Sullivan, P.B., Green, P.F., Bergman, S.C., Decker, J., Duddy, I.R., Gleadow, A.J.W., and Turner, D.L., 1993, Multiple phases of Tertiary uplift and erosion in the Arctic National Wildlife Refuge, Alaska, revealed by apatite fission track analysis: American Association of Petroleum Geologists Bulletin, v. 77, no. 3, p. 359-385.

O’Sullivan, P.B., Murphy, J.M., and Blythe, A.E., 1997, Late Mesozoic and Cenozoic thermotectonic evolution of the central Brooks Range and adjacent North Slope foreland basin, Alaska, including fission track results from the Trans-Alaska Crustal Transect (TACT): Journal of Geophysical Research, v. 102, p. 20,821-20,845.

O’Sullivan, P.B., Wallace, W.K., and Murphy, J.M., 1998, Fission-track evidence for apparent out-of-sequence Cenozoic deformation along the Philip Smith Mountains front, northeastern Brooks Range, Alaska: Earth and Planetary Science Letters, v. 164, p. 435-449.

Patton, W.W., Jr., 1956, New and redefined formations of Early Cretaceous age, in Gryc, George, and others, eds., Mesozoic sequence in Colville River region, northern Alaska: American Association of Petroleum Geologists Bulletin, v. 40, no. 2, p. 219-223.

Reger, R.D., Stevens, D.S.P., and Solie, D.N., 2008, Surficial-geologic map, Delta Junction to Dot Lake, Alaska Highway corridor: Alaska Division of Geological \& Geophysical Surveys Preliminary Interpretive Report 20083A, 48 p., 2 sheets, scale 1:63,360, doi:10.14509/17961.

Reifenstuhl, R.R., 1991, Gilead sandstone, northeastern Brooks Range, Alaska-An Albian to Cenomanian marine clastic succession, in Reger, R.D., ed., Short Notes on Alaskan Geology 1991: Alaska Division of Geological \& Geophysical Surveys Professional Report 111, p. 69-76, doi: $10.14509 / 2300$.

Reifenstuhl, R.R., Mull, C.G., Harris, E.E., LePain, D.L., Pinney, D.S., and Wallace, W.K., 2000, Geologic map of 
the Sagavanirktok B-1 Quadrangle, eastern North Slope, Alaska: Alaska Division of Geological \& Geophysical Surveys Report of Investigation 2000-1A, 15 p., 1 sheet, scale 1:63,360, doi:10.14509/2675.

Schenk, C.J., and Bird, K.J., 1993, Depositional sequences in Lower Cretaceous rocks, Atigun syncline and Slope Mountain areas, Alaska North Slope, in Dusel-Bacon, C., and Till, A.B., eds., Geologic studies in Alaska by the U.S. Geological Survey, 1992: U.S. Geological Survey Bulletin 2068, p. 48-58.

Stevens, D.S.P., Bowman, N.D., Reger, R.D., and Smith, R.L., 2003, Survey of geology, geologic materials, and geologic hazards in proposed access corridors in the Sagavanirktok Quadrangle, Alaska: Alaska Division of Geological \& Geophysical Surveys Miscellaneous Publication 106, 4 sheets, scale 1:250,000, doi:10.14509/3300.

Wartes, M.A., and Decker, P.L., 2008, Overview of recent geologic field investigations, North Slope and Brooks Range foothills, Alaska, in Wartes, M.A., and Decker, P.L., eds., Preliminary results of recent geologic field investigations in the Brooks Range Foothills and North Slope, Alaska: Alaska Division of Geological \& Geophysical Surveys Preliminary Interpretive Report 20081A, p. 1-10, 1 sheet, doi:10.14509/16085.

Wartes, M.A., Decker, P.L., Houseknecht, D.W., Gillis, R.J., and LePain, D.L., 2011a, Foreland basin response to
Paleocene rejuvenation in the Brooks Range, northern Alaska: American Association of Petroleum Geologists 3P Arctic Conference \& Exhibition, Halifax, Nova Scotia, Canada, 30 Aug 2011-2 Sept 2011, AAPG Search and Discovery Article \#90130.

Wartes, M.A., Wallace, W.K., Loveland, A.M., Gillis, R.J., Decker, P.L., Reifenstuhl, R.R., Delaney, P.R., LePain, D.L., and Carson, E.C., 2011b, Geologic map of the Kavik River area, northeastern Brooks Range, Alaska: Alaska Division of Geological \& Geophysical Surveys Report of Investigation 2011-3A, 14 p., 1 sheet, scale 1:63,360, doi: $10.14509 / 22602$.

Watts, A.B., Karner, G.D., and Steckler, M.S., 1982, Lithospheric flexure and the evolution of sedimentary basins: Philosophical Transactions of the Royal Society of London, A, v. 305, p. 249-281.

Waythomas, C.F., 1991, Surficial geologic maps of the Sagavanirktok A-1, A-2, and B-2 quadrangles, northeastern Brooks Range, Alaska: Alaska Division of Geological \& Geophysical Surveys Public Data File 91-21A, 5 p., 3 sheets, scale 1:63,360, doi:10.14509/1487.

Whittington, C.L., 1956, Revised stratigraphic nomenclature of Colville Group, in Gryc, George, and others, eds., Mesozoic sequence in Colville River region, northern Alaska: American Association of Petroleum Geologists Bulletin v. 40, p. 244-253. 